\title{
Stanowisko Jana Długosza wobec cudzoziemskich władców na tronie polskim
}

Roczniki Jana Długosza, jedno z najważniejszych dzieł piętnastowiecznej historiografii środkowoeuropejskiej, dostarczają wielu cennych informacji nie tylko o prezentowanej przez tego kronikarza wizji przeszłości Polski, ale również o dziejach obcych państw i krain oraz ich mieszkańców ${ }^{1}$. Znaczenie tego przekazu dla odtwarzania poglądów elit intelektualnych późnośredniowiecznej Polski odnośnie do odmiennych nacji i ziem przez nie zamieszkałych znajduje odzwierciedlenie w ciągle narastającej literaturze przedmiotu². Na tym

${ }^{1}$ Wedle wyliczeń historyków ponad $1 / 3$ relacji zamieszczonych na kartach monumentalnego dzieła Długosza dotyczyła dziejów powszechnych (M. Biskup: Jan Długosz (1415-1480) jako historyk Polski i krajów Europy Środkowo-Wschodniej. Zap. Hist. 1981, T. 46, z. 4, s. 44).

2 I. Minea: Informaţile Româneşti ale cronicii lui Ian Díugosz. Iaşi 1926, reedycja: Informaţiile româneşti în cronica lui Ian Dĺugosz. Bucureşti 1999; J. Mikulka: Annales Jana Dtugosza a Czechy. „Odrodzenie i Reformacja w Polsce” 1963, T. 8, s. 19-38; S. Solicki: Źródła Jana Długosza do problematyki czeskiej. Wrocław 1973; TenżE: Wiadomości geograficzne o Czechach w „Annales Poloniae” Jana Dlugosza. „Śląski Kwartalnik Historyczny Sobótka" 1981, T. 36, z. 1, s. 147-152; K. Pieradzka: Wiadomości o Burgundii u Jana Dlugosza. W: ZNUJ. Prace historyczne, nr 56. Kraków 1977, s. 73-79; M. Kupera: Jan Dlugosz a Slovensko. „Zborník Filozofickej Fakulty Univerzity Komenského. Historica“" 1983, R. 34, s. 61-89; A. Swieżawski: Bułgaria w Annales Poloniae Jana Dtugosza. „Balcanica Posnaniensia" 1985, T. 2, s. 255-265; R. Kościelny: Jan Dlugosz a Czechy w świetle Annales. „Szczecińskie Studia Historyczne” 1987, nr 1, s. 29—45; J. Krzyżaniakowa: Niemcy w opinii Jana Dlugosza. W: Polacy i Niemcy. Dziesięć wieków sąsiedztwa. Red. A. CzubiŃsKi. Warszawa 1987; W. Swoboda: Bizancjum w przekazach Annales Jana Dlugosza. „Balcanica Posnaniensia” 1989, T. 4, s. 27-55; R. Grzesik: Polska Piastów i Węgry Arpadów we wzajemnej 
tle szczególnie frapująco przedstawia się problem oceny przez Długosza pochodzących z krajów ościennych władców sprawujących rządy w państwie polskim. Do tej pory owo zagadnienie nie stało się przedmiotem odrębnych badań. Dysponujemy jedynie nielicznymi studiami szczegółowymi traktującymi o sposobie przedstawienia przez kronikarza poszczególnych panujących spoza dynastii piastowskiej ${ }^{3}$. Celem niniejszego artykułu będzie prześledzenie wyrażonych na kartach Roczników opinii dziejopisa na temat cudzoziemskich monarchów zasiadających na tronie polskim od przełomu XIII i XIV stule$\mathrm{cia}^{4}$. Dalsze rozważania nie będą koncentrować się na opisie rządów poszczególnych dynastów, lecz na analizie odnoszących się do nich poglądów i ocen kronikarza.

W artykule zostanie przybliżone stanowisko Długosza wobec trzech przedstawicieli obcych dynastii, którzy piastowali godność króla Polski, tj. Wacława II Przemyślidy, Ludwika I Andegaweńskiego oraz Władysława Jagiełły. Wszyscy oni pochodzili spoza ziem polskich i nie byli postrzegani przez dziejopisa jako

opinii (do 1320 roku). Warszawa 2003 (rozdz. III: Wiadomości o Wegrzech w ,,Rocznikach Królestwa Polskiego” Jana Dlugosza); J. Skomią: Jan Dlugosz o Litwie i Litwinach. W: Wielokulturowość polskiego pogranicza. Ludzie, idee, prawo. Red. A. LityŃski, P. FiedorczyK. Białystok 2003, s. 195-210; M. SzymańsKa: Opinia o Rusi do czasu właczenia do Polski Rusi Halickiej (1387), w „Kronice” Jana Długosza. „Kuźnia Młodych Historyków” 2004, T. 1, s. 41-57; Z. Pentek: Cesarstwo Lacińskie w oczach polskich dziejopisów od Jana Dlugosza do Macieja Stryjowskiego. „Balcanica Posnaniensia” 2013, T. 20, s. 41-45; L. KorczaK: Jan Dlugosz a Litwa - miejsca i ludzie. W: Jan Dlugosz (1415-1480). Życie i dzieła. Red. L. KorCZAK, M.D. Kowalski, P. WęCowski. Kraków 2016, s. 183-197; J. Nikodem: Żmudź i Żmudzini w opinii Jana Dlugosza. W: Jan Dlugosz 600-lecie urodzin. Region - Polska - Europa $w$ jego twórczości. Red. J. Maciejewski, P. Oliński, W. Rozynkowski, S. Zonenberg. Toruń-Bydgoszcz 2016; M. DĄBRowska: Jana Dlugosza spojrzenie na Bizancjum. W: Sic erat in votis. Studia i szkice ofiarowane Profesorowi Zbigniewowi Anusikowi w sześćdziesiata rocznicę urodzin. Europa i świat w czasach nowożytnych. Red. M. KARKOCHA, P. RoBAK. Łódź 2017, s. 59-80; A. Obara-Pawıowska: Obraz Wołochów w piśmiennictwie Jana Dlugosza. „Balcanica Posnaniensia” 2017, T. 24, s. 198-220.

3 J. Romańczuk: Olgierd i Kiejstut w opinii Dlugosza. „Kuźnia Młodych Historyków” 2004, T. 1, s. 65-72; J. NiкоDem: Spory o koronację wielkiego księcia Litwy Witolda w latach 1429-1430. Cz. 1: „Burza koronacyjna” w relacji Jana Dlugosza. „Lituano-Slavica Posnaniensia" 1994, T. 6, s. 55-75; TenżE: Spory o koronację wielkiego księcia Litwy Witolda w latach 1429-1430. Cz. 2: Próba rekonstrukcji wydarzeń. „Lituano-Slavica Posnaniensia” 1995, T. 7, s. 155-171; TenżE: Wróg Królestwa Polskiego. Zygmunt Luksemburski w opinii Jana Dlugosza. W: Cor hominis. Wielkie namiętności $w$ dziejach, źródłach i studiach nad przeszłościa. Red. S. Rosik, P. Wiszewski. Wrocław 2007, s. 183-199; J. SкомiaŁ: Polski portret litewskiego władcy. Witold Kiejstutowicz w świetle Annales Jana Długosza. W: „,Rodzinna Europa”. Europejska myśl polityczno-prawna u progu XXI wieku. Red. P. FIKTUS, H. MaLewsKI, M. Marszal. Wrocław 2015, s. 41-61; Ž. Mačıukas: Książe Witold Wielki w kampanii letniej 1410 r. w ocenie Jana Dtugosza. „Annales Universitatis Paedagogicae Cracoviensis. Studia Historica” 2011, nr 11, s. 113-125.

${ }^{4}$ Annales, lib. 1-2; lib. 3-4, 5-6, 9; lib. 10; lib. 10-11; lib. 11; lib. 11-12; lib. 12. Tłumaczenie polskie: Roczniki, ks. $1-2$; ks. 3-4, 5-6, 9; ks. 10, 10-11; ks. 11, 11 i 12, 12. 
„panowie przyrodzeni”, chociaż w przypadku Ludwika i Wacława Długosz wskazywał na ich mniej lub bardziej luźne związki z dynastią piastowską. Ponadto, Przemyślida i Andegawen wywodzili się z tego samego kręgu kulturowego, co Piastowie. Byli to władcy państw środkowoeuropejskich, które równocześnie weszły na arenę polityczną chrześcijańskiej Europy i praktycznie od początku swej państwowości pozostawały ze sobą związane na skutek zachodzących między nimi podobieństw oraz różnorakich zależności. Z kolei Jagiełło reprezentował dynastię sprawującą rządy na Litwie - w ostatnim pogańskim kraju Europy, który przez długi czas sytuował się na uboczu głównych nurtów rozwojowych Starego Kontynentu, pozostając jednocześnie obszarem narażonym na wyprawy misyjne organizowane przez chrześcijańskich sąsiadów. W przypadku wszystkich trzech monarchów ich obcość była powiązana z czynnikiem geograficznym (przybycie z innego państwa), w odniesieniu do Jagiełły zaś dodatkowo z jego pierwotną odmiennością religijną ${ }^{5}$.

Przy próbach zrekonstruowania wizerunku obcego władcy trzeba mieć na uwadze stosunek dziejopisa do przedstawicieli państw ościennych. Skądinąd wiadomo, że był on niechętnie nastawiony do mieszkańców sąsiednich krajów, surowo oceniał przedstawicieli innych nacji, niejednokrotnie odwoływał się do negatywnych stereotypów ${ }^{6}$, przy czym nie wolno zapominać, że równie bezkompromisowe sądy wygłaszał pod adresem rodaków. Nie wchodząc w szczegółowe analizy, można wskazać podstawowe wady przypisane przez kronikarza nacji czeskiej, węgierskiej i litewskiej. Węgrom zarzucał nadmierne dążenie do zmian, niestałość, hardość, a sami Panończycy w jego ujęciu nie byli godni zaufania ${ }^{7}$. Czesi z kolei pozostawali butni i dumni z natury, przebiegli, skłonni do grabieży i niewdzięczni ${ }^{8}$. Niechęć Długosza do Czechów potęgowała jego antypatia do husytów, którą przenosił także na przodków

${ }_{5}^{5}$ Przywołane kategorie, tj. przestrzeń geograficzna i czynnik religijny, były podstawowymi w wiekach średnich elementami składającymi się na poczucie jedności, definiując tym samym „obcego" (D.B. Leshock: Religious Geography: Designating Jews and Muslims as Foreigners in Medieval England. In: Meeting the Foreign in the Middle Ages. Ed. A. Classen. New York-London 2002, s. 202-203).

6 S. GawęDA: Ocena niektórych problemów historii ojczystej w „Rocznikach” Jana Dtugosza. W: Dlugossiana. Studia historyczne w pięćsetlecie śmierci Jana Dlugosza. Red. S. GAWĘDA. Warszawa 1980, s. 196-197; S. Gawlas: Świadomość narodowa Jana Dlugosza. St. Źr. 1983, T. 27, s. 47; M. KoczersKa: Mentalność Jana Dtugosza w świetle jego twórczości. St. Źr. 1970, T. 15, s. 132-133. W swoich Rocznikach Długosz zamieścił portrety trzech złych władczyń, tj. żony Popiela, Rychezy i Agnieszki, małżonki Władysława Wygnańca. Łączyło je niemieckie pochodzenie oraz pogarda dla Polaków i nienawiść do nich (K. SzAfer: Wizerunek dobrej i złej władczyni w Rocznikach Jana Dlugosza. W: Kobieta w kulturze średniowiecznej Europy. Prace ofiarowane Profesor Alicji Karłowskiej-Kamzowej. Red. A. GĄSIOrowski. Poznań 1999, s. 91-92).

7 Annales, lib. 3-4, s. 326.

${ }^{8}$ Np.: tamże, s. 33, 319-320. 
współczesnych mu mieszkańców Bohemii9. Stosunek kronikarza do Litwinów warunkowany był faktem ich długoletniego przywiązania do wierzeń pogańskich, licznymi najazdami rabunkowymi organizowanymi na ziemie polskie oraz przekonaniem o szczególnej roli Polski wobec ziem litewskich, co rodziło poczucie wyższości ${ }^{10}$. Poddani książąt litewskich i oni sami byli początkowo przedstawiani jako typowy lud pogański oraz barbarzyński, nękający łupieżczymi najazdami swoich sąsiadów. Dopiero chrystianizacja wprowadziła ich do kręgu cywilizowanej społeczności europejskiej, co jednak nie zmieniło negatywnej oceny wystawianej im przez Długosza ${ }^{11}$. W opisie Litwinów „najprymitywniejszego ludu północy”"2 — kanonik krakowski podkreślał ich skłonność do oszustw oraz pijaństwo czy tchórzostwo ${ }^{13}$. Wskazane negatywne cechy przypisywane przez dziejopisa poszczególnym nacjom nie zawsze musiały automatycznie charakteryzować cudzoziemców na tronie polskim, na pewno jednak uwidaczniały się w postawie Długosza wobec obcych przybywających z monarchą do kraju.

Bardzo istotne pozostaje również ustalenie źródeł, z których dziejopis czerpał informacje na temat cudzoziemskich władców. Panowanie Wacława II

9 J. Mikulka: Annales Jana Dlugosza..., s. 35; U. Borkowska: Treści ideowe w dziełach Jana Dlugosza. Kościół i świat poza kościołem. Lublin 1983, s. 146. Na obraz Czechów w Rocznikach Jana Długosza wpływ miał także polonocentryzm, a więc patrzenie na sprawy słowiańskich sąsiadów przez pryzmat postulowanej przez Długosza roli Polski we wspólnocie słowiańskiej oraz związane z tym przekonanie o zasadności unifikacji ludności czeskiej pod przewodnictwem państwa polskiego. Niemniej jednak zwraca się uwagę na fakt, że kronikarz potrafił wypowiadać się w sposób pozytywny o mieszkańcach Bohemii, doceniając np. ich męstwo w walce. Co więcej, Długosz był świadomy, że w społeczeństwie czeskim nie wszyscy byli zwolennikami herezji, a chętnie eksponowany przez niego husytyzm, przy podkreślaniu ortodoksji katolickiej Polaków, miał na celu pomniejszenie wad narodu polskiego (R. Kościelny: Jan Dtugosz a Czechy..., s. 29-31, 39).

${ }^{10}$ M. Koczerska: Mentalność..., s. 134; M.T. Zahajkiewicz: Chrzest Litwy. Wprowadzenie. Problem chrztu Litwy w historiografii. W: Chrzest Litwy. Geneza, przebieg, konsekwencje. Red. M.T. ZAHAJKIEWICZ. Lublin 1990, s. 34.

11 J. Skomial: Polski portret..., s. 46. Jeszcze w 1438 r. przeciwnicy osadzenia na tronie czeskim królewicza Kazimierza rozpowszechniali paszkwile na jego temat, zarzucając mu, że jest „synem poganina” (M. BogucKa: Kazimierz Jagiellończyk i jego czasy. Kraków 2009, s. 46).

12 Warto zwrócić baczniejszą uwagę na częste określanie przez Długosza Litwinów mianem ludu północy. Nie chodziło tylko o wskazanie geograficznego położenia ich siedzib. W okresie średniowiecza północ była postrzegana jako ostoja barbarzyństwa, dzikości i pogaństwa (więcej zob.: A. PleszCZyński: Niemcy wobec pierwszej dynastii piastowskiej (9631034). Narodziny stereotypu. Postrzeganie i cywilizacyjna klasyfikacja władców Polski i ich kraju. Lublin 2008, s. 27-38). O trwałości tego sposobu postrzegania północy mogą świadczyć słowa Macieja z Miechowa, który w 1517 r. w swoim Opisie Sarmacji... określał tę stronę świata jako miejsce, skąd pochodzi całe zło (Macıej z Miechowa: Opis Sarmacji azjatyckiej i europejskiej. Wstęp H. BARYCZ. Tłum. T. BieŃKowski. Wrocław-Warszawa-KrakówGdańsk 1972, s. 56).

${ }^{13}$ Szczegółowa analiza cech Litwinów: J. Skomia£: Jan Dlugosz o Litwie..., s. 201-209. 
zostało przedstawione na podstawie powstałej ok. 1374 roku Kroniki Pulka$w y^{14}$. Wskazuje się tu także na materiały pochodzące z klasztorów cysterskich, znane Długoszowi, a odnoszące się do panowania Wacława II w Polsce ${ }^{15}$. Z kolei podstawowe znaczenie dla opisu rządów oraz osoby Ludwika Węgierskiego w Polsce miała Kronika Janka z Czarnkowa ${ }^{16}$. W odniesieniu do Władysława Jagiełły kronikarz miał możliwość wykorzystania liczniejszych źródeł, w tym nie tylko przekazów pisanych ${ }^{17}$, ale również tradycji ustnej przekazanej mu przez członków jego rodziny ${ }^{18}$, patronów politycznych (Zbigniew Oleśnicki, Tarnowscy, Tęczyńscy), polskich uczestników wypraw na Litwę ${ }^{19}$ czy wreszcie obserwacji własnej (w 1431 roku Jan Długosz rozpoczął pracę w kancelarii biskupa Oleśnickiego, co stwarzało sposobność częstych spotkań z sędziwym $\mathrm{kró} \mathrm{em}^{20}$ ). Podsumowując problem źródeł wykorzystanych przez dziejopisa, zwłaszcza tych odnoszących się do dawniejszych czasów, należy oddzielić sferę przytaczanych przezeń faktów i opisów wydarzeń — te mogły być wprost przejmowane od innych autorów — od samodzielnych opinii i ocen formułowanych przez kronikarza ${ }^{21}$. W komentarzach narratorskich Długosz dążył do

${ }^{14}$ A. Semkowicz: Krytyczny rozbiór Dziejów polskich Jana Dlugosza (do roku 1384). Kraków 1882, s. 61-62, 321-329.

15 J. Mikulka: Annales Jana Dtugosza..., s. 25-26.

16 A. Semkowicz: Krytyczny rozbiór Dziejów polskich..., s. 31-32. Wykaz informacji zawartych w Rocznikach, a związanych z osobą Ludwika, pochodzących z bliżej nieznanego źródła, zob. tamże, s. 63-64. Więcej na temat oceny panowania Andegawenów w Polsce przez Jana Długosza zob. J. Niкodem: Jan Dlugosz o rzadach andegaweńskich w Polsce. W: Jan Dlugosz - w kręgu badań historyków i literaturoznawców. Red. T. Giergiel. Sandomierz 2017, s. 93-106.

${ }_{17} \mathrm{O}$ źródłach pisanych, które wykorzystywał Długosz, opisując Jagiełłę i jego rządy, zob.: Rozbiór krytyczny Annalium Poloniae Jana Dlugosza. T. 1: Z lat 1285-1444. Oprac. S. GAWĘDA i in. Wrocław 1961, passim; S.M. KuCZYŃski: Rozbiór krytyczny roku 1385 „Dziejów polskich” Jana Dtugosza. St. Źr. 1958, T. 3, s. 213-254; K. BiedrowsKa-OchmańskA, J. Ochmański: Władysław Jagiełto w opiniach swoich wspótczesnych. Próba charakterystyki jego osobowości. Poznań 1987, s. 71-74.

${ }_{18}$ Zarówno ojciec Długosza Jan, jak i stryj Bartłomiej brali udział w bitwie pod Grunwaldem. Ojciec wsławił się pojmaniem komtura Brandenburga Markwarda von Salzbacha wraz z kilkoma rycerzami, zaś stryj, kapelan królewski i proboszcz kłobucki, odprawił mszę przed walką (M. Bobrzyński, S. Smolka: Jan Dtugosz, jego życie i stanowisko w piśmiennictwie. Kraków 1893, s. 3-4; reprint: Kraków 2015). Obaj bracia byli związani z osobą króla Władysława. Jan Długosz senior za zasługi pod Grunwaldem uzyskał zapis 250 grzywien na wsi królewskiej Kocin, pełnił funkcję starosty Nowego Miasta Korczyna, jak również „bliżej nieokreślone, choć raczej nie podrzędne, funkcje na dworze królewskim" - W. BuKowski: Krąg rodzinny Jana Dtugosza. W: Jan Dtugosz (1415-1480).., s. 23-25.

${ }_{19}$ Rozbiór krytyczny..., s. LIII.

${ }^{20}$ Przyszły kronikarz miał możliwość spotkać króla Władysława Jagiełłę w dzieciństwie, które spędził w Nowym Korczynie, gdzie władca bywał bardzo często (A. GĄSIORowski: Itinerarium króla Władysława Jagiełty 1386-1434. Warszawa 1972, s. 102).

${ }^{21}$ D. WróBeL: Bezkrólewie, małoletniość i nieobecność władcy w Rocznikach Jana Długosza. W: Jan Dlugosz (1415-1480).., s. 224. 
lepszego wyjaśnienia przyczyn zdarzeń czy motywów, jakimi kierowali się jego bohaterowie, co nie zawsze wiązało się z zachowaniem bezstronności ${ }^{22}$. Właśnie w takich wypowiedziach można odnaleźć poglądy dziejopisa dotyczące nie tylko rządów wskazanych władców, ale również ich cech osobistych.

Zasadniczo Jan Długosz uznawał rządy obcego monarchy za sytuację mało korzystną dla Królestwa i jego mieszkańców. Dał temu wyraz, np. opisując okoliczności zawarcia małżeństwa przez księcia krakowskiego Leszka Białego. Panujący miał zdecydować się na ten krok pod presją panów małopolskich, którzy obawiali się, że w razie bezpotomnej śmierci jego i jego brata Konrada będą zmuszeni podlegać władzy obcych książąt (,,in peregrinorum ducum dicionem devenire cogerentur" ${ }^{23}$. Kronikarz wygłaszał też bardzo zdecydowane poglądy na temat przyczyn wygaśnięcia rodzimej dynastii piastowskiej. Jego zdaniem „diadema Regni Polonie a veris, iustis et naturalibus principibus, ob varias prevaricaciones et dolos in alienigenas et exteros iusto Dei permittente iudicio translatum" ${ }^{24}$. Pojawienie się cudzoziemców na tronie polskim rozpatrywał Długosz w kategoriach kary za grzechy. I tak, Władysław Łokietek przejściowo utracił władzę na rzecz Przemyślidy, co było karą za ciemiężenie własnych poddanych i brak dbałości o bezpieczeństwo państwa ${ }^{25}$. Z kolei zerwanie przez panów polskich pełnoprawnego małżeństwa Jadwigi z Wilhelmem Habsburgiem skutkowało, zdaniem Długosza, pojawieniem się w Polsce bezładnych rządów władców z dynastii jagiellońskiej, którzy bardziej sprzyjali Litwinom niż Polakom ${ }^{26}$. Ukazanie momentu objęcia tronu przez przedstawicieli niepiastowskich dynastii jako kary za grzechy popełnione przez Polaków wyraźnie wskazuje na niechętne stanowisko dziejopisa w tej kwestii.

Przedstawiając przyczyny przejścia władzy monarszej $\mathrm{w}$ ręce zagranicznych dynastów, Długosz w każdym z trzech przypadków bardzo wyraźnie akcentował czynny udział uprawomocnionych warstw społecznych w powołaniu nowego władcy/nowej dynastii. Kronikarz, opowiadając się za dziedziczeniem jako podstawowym i najbardziej liczącym się tytułem do tronu w Polsce ${ }^{27}$, podkreślał równocześnie prawa panów polskich do wyboru monarchy. $\mathrm{W}$ ten sposób próbował pogodzić swe patriotyczne nastawienie (optowanie za prawami przyrodzonych władców) z przekonaniami środowiska, z którym był związany,

${ }^{22}$ U. Borkowska: Historiograficzne poglady Jana Dlugosza. W: Dlugossiana. Studia historyczne w pięćsetlecie śmierci Jana Dtugosza. Red. S. GAwęDA. Cz. 2. Warszawa-Kraków 1985, s. 66-69; M. RzePIEla: Rola frazeologii w narracji Kroniki Jana Dlugosza. W: Jan Dlugosz (1415-1480)..., s. 246.

${ }_{23}$ Annales, lib. 6, s. 231.

24 Tamże, lib. 10, s. 21, podobnie: tamże, s. 92 i 155.

${ }_{25}$ Tamże, lib. 9, s. 11.

26 Tamże, lib. 10, s. 154.

27 R. SовоткA: Powolywanie władcy w Rocznikach Jana Dlugosza. Warszawa 2005, s. 187. Kolejnymi pod względem ważności tytułami do tronu polskiego były u Długosza elekcja i desygnacja (tamże). 
o prawie poddanych (elity) do wpływu na obsadę tronu, aż po zakwestionowanie reguły dziedziczenia. Patriotyzm kronikarza, podbudowany przykładami płynącymi z dzieł historiograficznych (Kronika Wincentego Kadłubka, Komentarz Jana z Dąbrówki), konfrontował się z uznawaną w jego czasach praktyką obsadzania tronu. Wraz z nabywaniem przez górne warstwy społeczeństw państw Europy Środkowej (Polska, Czechy, Węgry) mniemania, że są one podmiotem władzy, odpowiedzialnym za losy kraju, zaczęło kształtować się przekonanie, że wybór najlepszego kandydata do tronu stanowi ich naturalne prawo ${ }^{28}$. Jednak powołani $\mathrm{w}$ drodze elekcji władcy cudzoziemscy przy niewystarczających prawach dziedzicznych do korony polskiej lub wręcz braku takowych byli traktowani przez dziejopisa z dużą dozą sceptycyzmu i nieufności.

Lektura monumentalnego dzieła Jana Długosza pozwala wyodrębnić zarówno korzyści, jak i zagrożenia płynące z wyboru cudzoziemca, przy czym tych pierwszych jest zdecydowanie mniej. Zależność obcego władcy od przywołujących go na tron panów polskich sprawiała niekiedy, że cudzoziemcy rządzili sprawiedliwiej i bardziej umiarkowanie niż rodzimi dynaści (,externi iustius modestiusque quam proprii principes imperitent") ${ }^{29}$. Ta pobłażliwość wobec poddanych wynikała z konieczności zapewnienia sobie poparcia i ugruntowania własnej pozycji w nowym państwie. Ponadto, monarcha taki, dążąc do pozyskania zwolenników na nowo opanowanych ziemiach polskich, mógł być bardziej skłonny do likwidacji niektórych ciężarów, a efektem jego działań było nastanie tak upragnionego pokoju i różne korzyści zeń płynące ${ }^{30}$. Ład wprowadzony przez Przemyślidę przejściowo łagodził gorycz poddania się rządom z natury pełnych pychy i znienawidzonych Czechów ${ }^{31}$. Podkreśla-

${ }^{28}$ S. Russocki: Średniowieczne narody polityczne środkowej Europy. CP-H 1985, T. 37, z. 2, s. 64-65; TenżE: Struktury i świadomość. Procesy integracji rycerstwa Europy Środkowej schyłku XIII w. i ich odbicie w historiografii epoki. W: Społeczeństwo Polski średniowiecz$n e j$. Red. S.K. KucZyŃsKi. T. 1. Warszawa 1981, s. 214-215.

${ }^{29}$ Annales, lib. 9, s. 17.

30 Tamże.

${ }^{31}$ Tamże. Podobnie rzecz miała się w kwestii panowania w Wielkopolsce księcia śląskiego Henryka głogowskiego, który przez kronikarza był traktowany jako przedstawiciel obcej dynastii. W ujęciu Długosza Henryk miał żywić głęboki wstręt i pogardę dla wszystkiego, co polskie (tamże, s. 38). Wspomnienie w tym miejscu o władcy śląskim wydaje się o tyle zasadne, że sam Długosz uznawał Ślązaków za odrębną od Polaków nację. Wystarczy przywołać jego słowa ilustrujące wrogość i zawiść Ślązaków wobec Polaków, wedle których: „Nec ulla gens in vicinatu Regni Polonie consistens fertur esse Polonis, quantum gens Slesitica, magis aut invida aut infesta" - tamże, s. 136. W innym miejscu, opisując okoliczności wyznaczenia w 1339 r. królewicza Ludwika Andegaweńskiego następcą Kazimierza Wielkiego, kronikarz określił książąt ze śląskiej linii Piastów mianem zdrajców, którzy bez konieczności i przymusu porzucili własny naród oraz wyrzekli się swojego języka i ojczyzny (tamże, s. 211-212). Podobne słowa pod adresem monarchów śląskich, niezasługujących $\mathrm{z}$ tego powodu na koronę Królestwa Polskiego, zostały sformułowane wcześniej przez Janka z Czarnkowa (Kronika Janka z Czarnkowa. Wyd. A. Bielowski. W: MPH, T. 2, s. 645-646). 
nie umiejętności zaprowadzenia przez czeskich władców porządku wewnętrznego, co przynajmniej na pewien czas stanowiło wystarczający czynnik dla stabilizacji ich rządów na ziemiach polskich, wygląda na próbę wyjaśnienia czy wręcz usprawiedliwienia przez autora Roczników braku poparcia miejscowych możnych dla przedstawiciela rodzimej dynastii piastowskiej ${ }^{32}$.

W ujęciu Długosza panowie polscy, powołując na tron wielkiego księcia litewskiego Jagiełłę, liczyli na wzmocnienie państwa dzięki poszerzeniu jego terytorium ${ }^{33}$ oraz doprowadzenie za pośrednictwem Polski do chrystianizacji Litwy i Żmudziji ${ }^{34}$. Każde działanie króla zmierzające do jak najściślejszego zespolenia tych terenów z ziemiami Korony zyskiwało pełną akceptację kronikarza ${ }^{35}$. $Z$ jednej strony przemawiało przez niego umiłowanie ojczyzny, stąd wszelkie przychylne komentarze przy zabiegach mających na celu wzmocnienie państwa czy podniesienie jego prestiżu na arenie międzynarodowej. Z drugiej zaś strony Długosz jako duchowny równie entuzjastycznie podchodził do wszelkich inicjatyw ugruntowujących pozycję Kościoła.

O wiele częściej kronikarz akcentował jednak zagrożenia, jakie niosło ze sobą panowanie obcych monarchów. Wśród najbardziej oczywistych niebezpieczeństw wymieniał brak przywiązania cudzoziemskiego panującego do nowych ziem ${ }^{36}$. O wiele poważniejsze były sytuacje, w których dostrzegał zaniedbanie interesów Królestwa Polskiego z korzyścią dla drugiego z władztw monarchy. Mocne zarzuty kierował kronikarz pod adresem Ludwika I, którego oskarżył o działanie na szkodę ziem polskich ${ }^{37}$. Bardzo krytycznie ocenił również postanowienia pokoju toruńskiego z 1411 roku, wprost zarzucając królowi

${ }^{32} \mathrm{~W}$ ten sam sposób Długosz wyjaśniał odrzucenie w 1306 r. przez panów duchownych i świeckich z Wielkopolski kandydatury Władysława Łokietka do objęcia władzy w tej dzielnicy. Nieprzychylny Henrykowi głogowskiemu i jego aspiracjom politycznym kronikarz z uznaniem podkreślał jednak, że książę ten surowo karał wszystkich przestępców, dzięki czemu rządzona przez niego po śmierci Wacława II Wielkopolska mogła cieszyć się bezpieczeństwem i pokojem (Annales, lib. 9, s. 37-38).

33 Tamże, lib. 10, s. 144. Niemniej jednak — jak zauważył dziejopis — poszerzenie terytorium państwa o ziemie litewskie miało swoją cenę. Aby utrzymać nowe nabytki, Polacy musieli aktywnie wspierać stronę litewską w jej walce z Krzyżakami. Król Władysław II popierał te działania, przeznaczając dla rycerzy polskich biorących udział w tych kampaniach środki ze skarbu monarszego oraz wynagradzając ich dobrami ziemskimi w Królestwie Polskim (tamże, s. 203). O źródłach tej informacji zob.: Rozbiór krytyczny..., s. 40.

${ }^{34}$ Annales, lib. 10, s. 144; lib. 11, s. 21-26. Więcej na ten temat: U. BorkowsKa: Treści ideowe..., s. 132-133; M.T. ZahaJkiewicz: Chrzest Litwy..., s. 34.

35 Annales, lib. 11, s. 14-21.

36 Tamże, lib. 10, s. 25.

37, ,... Regni Polonie corpus per plures alias alienaciones multipharie mutilum et distractum, ampliori scissura ebetat et corrumpit, ut prorsus etiam tunc appareret Ludowigum regem ditissimo Hungarie Regno locupletem, nichil pensi de Regno Polonie stabiliendo aut de hiis, que illi a Bohemis, Saxonibus et Cruciferis abstracta erant, vindicandis habuisse neque de illius profectu et incremento, sed de disembracione cogitaciones et curas intendisse" - tamże, s. 18. 
Władysławowi II oraz jego kuzynowi wielkiemu księciu Witoldowi ${ }^{38}$, mającym na uwadze przede wszystkim zachowanie integralności terytorialnej Wielkiego Księstwa Litewskiego, nieprzywiązywanie należytej wagi do odzyskania terenów Królestwa Polskiego, tj. Pomorza, ziemi chełmińskiej i michałowskiej, a tym samym zaprzepaszczenie korzyści zwycięstwa grunwaldzkiego ${ }^{39}$. Z podobnym oburzeniem kanonik krakowski oceniał zamiar Władysława II oddania Świdrygielle zamków podolskich (,,plus sibi et Lithuani de terra quam proprio Regno favebat" ${ }^{\text {"40 }}$ ).

Z przedstawionym problemem wiąże się lekceważenie drugiego królestwa i jego mieszkańców. W Rocznikach Długosza przekonanie to znalazło odzwierciedlenie chociażby w słowach, jakie miał wypowiedzieć Przecław Wąwelski (Krzesław z Wywły ${ }^{41}$ ), który w imieniu panów i prałatów Królestwa Polskiego domagał się od królowej Elżbiety Bośniaczki przysłania do Polski jej córki Jadwigi. Kronikarz włożył w usta posła stanowcze stwierdzenie, by królowa Węgier zaprzestała czynić z Polaków pośmiewisko ${ }^{42}$. Ponadto, rządy obcego władcy niosły zagrożenie mniej lub bardziej świadomego naruszania obowiązującego w Królestwie Polskim prawa. Zarzut taki pojawił się przy okazji ustanowienia przez Ludwika I księcia Władysława Opolczyka namiestnikiem królewskim w Polsce. Panowie polscy zebrani zdaniem Długosza na dwóch zjazdach, w Gnieźnie i Wiślicy ${ }^{43}$, argumentowali, że nie jest właściwe, aby rządził nimi książę niezatwierdzony i niewybrany przez nich, a narzucony przez króla ${ }^{44}$. W podobnie negatywny sposób kronikarz ocenił wyposażenie namiestnika Królestwa Polskiego, biskupa krakowskiego Zawiszy w możliwość

${ }^{38}$ Zdaniem autorów Rozbioru krytycznego... wyraźne oskarżenie Witolda o zawarcie tak niekorzystnego z punktu widzenia interesów państwa polskiego układu mogło stanowić odzwierciedlenie poglądów przekazanych kronikarzowi przez Zbigniewa Oleśnickiego (Rozbiór krytyczny..., s. 133-134).

39 Annales, lib. 10-11, s. 177-178. Długosz w gorzkim podsumowaniu stwierdził, że zwycięstwo owo nie przyniosło żadnej korzyści Królestwu Polskiemu, a jedynie Księstwu Litewskiemu (tamże, s. 178).

40 Tamże, lib. 11, s. 311.

${ }^{41}$ J. TęGowski: Bezkrólewie po śmierci Ludwika Węgierskiego a geneza unii Polski z Litwa. W: Studia historyczne z XIII-XV wieku. Red. J. ŚliwiŃsKI. Olsztyn 1995, s. 105.

42 Annales, lib. 10, s. 137.

43 Janko z Czarnkowa przekazał jedynie informację o zjeździe w Gnieźnie. Wiadomość Długosza o wiecu, który miał odbyć się również w Wiślicy, miała podkreślić solidarną postawę możnych wielko- i małopolskich występujących przeciwko kandydaturze księcia śląskiego na namiestnika Królestwa Polskiego (A. SEmKowicz: Krytyczny rozbiór Dziejów polskich..., s. 390) czy wręcz dowartościować Małopolan (J. SPERKA: Rzady namiestnicze Władysława Opolczyka w Królestwie Polskim. W: Mieszczanie, wasale, zakonnicy. Red. B. ŚLiwiński. Malbork 2004, s. 259). Najnowsze podsumowanie tematu namiestniczych rządów Władysława Opolczyka zob. A. Marzec: Pod rządami nieobecnego monarchy. Królestwo Polskie 13701382. Kraków 2017, s. 148-159.

${ }^{44}$ Annales, lib. 10, s. 61. 
nadawania wszystkich godności i urzędów w Polsce, z wyjątkiem kasztelana i wojewody krakowskiego. Powodem krytyki było nie tylko sprzeniewierzenie się przez monarchę dotychczasowej tradycji. W ocenie dziejopisa panowie polscy uznali wprowadzone rozwiązanie za haniebne i przyczyniające się do powstania zawiści między nimi ${ }^{45}$. O mniej lub bardziej świadome łamanie obowiązujących w Polsce zwyczajów często oskarżany był przez kronikarza Władysław Jagiełło. W 1386 roku Długosz przekazał informację o żądaniu przez króla stacji od kapituły gnieźnieńskiej w trakcie jego monarszej podróży do Wielkopolski. Niesprawiedliwość władcy, skutkująca skargami kmieci ze wsi kościelnych, została naprawiona przez króla Jadwigę ${ }^{46}$.

Powszechnymi zarzutami wobec cudzoziemskiego monarchy, jednocześnie dzierżącego tron w swym rodzimym państwie, były jego notoryczna nieobecność w Polsce i sprawowanie rządów za pośrednictwem wyznaczonych osób, niejednokrotnie obcego pochodzenia. Tak było zarówno w przypadku Wacława II, który po opuszczeniu swych polskich włości wyznaczał śląskich i czeskich starostów dla poszczególnych dzielnic Polski ${ }^{47}$, jak i Ludwika Węgierskiego, który odwoływał się do pomocy swej matki Elżbiety ${ }^{48}$, Władysława Opolczyka ${ }^{49}$ oraz biskupa krakowskiego Zawiszy, kasztelana krakowskiego Dobiesława oraz starosty krakowskiego Sędziwoja z Szubina ${ }^{50}$. Stała nieobecność króla powodowała różnego rodzaju zagrożenia dla bezpieczeństwa państwa, zarówno w wymiarze zewnętrznym, jak i wewnętrznym. Jednym z najbardziej wymownych przykładów była, powtórzona za Jankiem z Czarnkowa, informacja o napadzie litewskim na ziemię sandomierską w 1376 roku i niefrasobliwej postawie królowej Elżbiety, sprawującej w tym czasie rządy w Królestwie Polskim w imieniu Ludwika ${ }^{51}$. Z kolei w 1380 roku Kościół polski musiał wysłać swoich przedstawicieli aż do Budy w celu zaniesienia skarg na krzywdy, jakich doznawał ze strony rycerstwa, oraz prośby o jak najszybszą interwencję monarszą ${ }^{52}$. W tym kontekście nie dziwi więc dziejopisa postawa panów wielkopolskich, którzy po śmierci Ludwika obiecali Zygmuntowi Luksemburczykowi

45 Tamże, s. 76.

46 Tamże, s. 158. Szczegółowa relacja o zatargu króla z arcybiskupem i kapitułą pojawia się jedynie u Długosza. O prawdopodobnych źródłach tej informacji zob.: Rozbiór krytyczny..., s. $13-14$.

47 Annales, lib. 9, s. 16-17.

48 Tamże, lib. 10, s. $24-25,50-52$.

49 Tamże, s. $60-61$.

${ }^{50}$ Tamże, s. 75-76.

51 Tamże, s. 51-52.

52 Tamże, s. 73-74. Nie zidentyfikowano źródła tej informacji (A. Semkowicz: Krytyczny rozbiór Dziejów polskich..., s. 392). Kościół polski był jednym z podmiotów doznających uszczerbku na skutek kryzysów państwa związanych z bezkrólewiem czy nieobecnością króla. Sytuacje tego rodzaju były przez kronikarza szczególnie mocno akcentowane (D. WróBel: Bezkrólewie, matoletniość i nieobecność władcy..., s. 228-229). 
posłuszeństwo pod warunkiem usunięcia nielubianego Domarata z Pierzchna ze stanowiska starosty wielkopolskiego oraz deklaracji zamieszkania w Królestwie Polskim ${ }^{53}$. Przedłużająca się absencja władcy prowadziła do coraz większego niezadowolenia jego poddanych, stwarzając zagrożenie wybuchem buntu ${ }^{54}$. Warunek osiedlenia się i stałego przebywania na terenie Królestwa Polskiego jednej z córek Ludwika wraz z jej mężem wielokrotnie pojawiał się w żądaniach, jakie na kartach dzieła Długosza formułowali panowie polscy, grożąc, w razie niespełnienia ich roszczeń, powołaniem nowego $\mathrm{króla}^{55}$. Z relacji zawartych w Rocznikach wyłania się jednoznacznie negatywny obraz rządów namiestniczych. Dziejopis traktował taki sposób zarządzania państwem w kategoriach degradacji Królestwa Polskiego. Niewykluczone, że negatywna ocena tej sytuacji oraz niemal permanentnej nieobecności cudzoziemskiego monarchy w kraju wynikała po części z doświadczeń pokolenia kronikarza, związanych z wyjazdem Władysława Warneńczyka na Węgry oraz przedkładaniem interesów tego państwa nad dobro Polski ${ }^{56}$.

Kolejny problem stanowiło otaczanie się przez obcego monarchę własnymi rodakami, co zdaniem dziejopisa prowadziło do nadużyć $\mathrm{z}$ ich strony względem miejscowej ludności. Długosz, za Jankiem z Czarnkowa, przytoczył opinię, że tuż po objęciu władzy przez Ludwika przebywający u jego boku Węgrzy krzywdzili mieszczan i wieśniaków, przywłaszczając sobie rzeczy do nich należące, oraz uniemożliwiali zaniesienie przed oblicze królewskie skargi na takie postępowanie ${ }^{57}$. Rezultatem tych niegodziwości była rzeź Węgrów w Krakowie, sprowokowana przez samych Madziarów ${ }^{58}$. Do niepożądanych sytuacji dochodziło jednak w dalszym ciągu. Nie dziwi więc, że według kronikarza jedną z głównych przyczyn niechęci do Zygmunta Luksemburczyka jako potencjalnego (współ)władcy Królestwa Polskiego miało być popieranie przez niego Czechów, przy jednoczesnym upokarzaniu Polaków (wyrzucanych z komnaty, gdy margrabia zasiadał do posiłku) ${ }^{59}$.

Innym zagrożeniem związanym z dzierżeniem tronu przez obcego władcę było uszczuplanie terytorium państwa. Ludwik I, mając na uwadze bogactwo i dogodne położenie ziem ruskich, postanowił oderwać je od Królestwa Polskiego i przyłączyć do swojego węgierskiego władztwa, nadając tamtejsze zamki, miasta i wsie Węgrom. Długosz podsumował te działania przestrogą na przy-

${ }_{53}$ Annales, lib. 10, s. 103. W tym miejscu Jan Długosz włożył w usta panów wielkopolskich znamienne słowa wyrażające przekonanie, że nieobecność władcy naraziła Królestwo Polskie na różne katastrofy i klęski (tamże).

${ }^{54}$ Tamże, s. 60.

55 Tamże, s. 118, 137.

56 Z. Perzanowski: Kanonik krakowski ks. Jan Dlugosz o królowej Jadwidze. „Analecta Cracoviensia” 1980, T. 12, s. 198.

57 Annales, lib. 10, s. 24. Podobnie u Janka z Czarnkowa: Kronika..., s. 648-649.

58 Annales, lib. 10, s. 53-54.

59 Tamże, s. 106. 
szłość, by nie zrównywać władców obcych z rodzimymi, jako że rządy tych drugich doprowadziły do dezintegracji Królestwa Polskiego ${ }^{60}$. Podobna sytuacja rozegrała się na początku panowania Władysława II. Monarcha ten, chcąc zjednać sobie księcia mazowieckiego Siemowita, postanowił przekazać mu tytułem posagu swojej siostry Aleksandry najpierw ziemię radomską, a później — pod wpływem protestów panów polskich — bełską. Darowizna ta spotkała się z krytyką ze strony dziejopisa, który argumentował, że ziemia bełska stanowiła integralną część Królestwa, a jej donacja odbyła się ze szkodą dla państwa polskiego ${ }^{61}$. Przypadki tego rodzaju zwracały szczególną uwagę Długosza ${ }^{62}$, wyczulonego na wszelkie przejawy uszczuplania terytorium monarchii polskiej ${ }^{63}$. Jeżeli weźmiemy pod uwagę znaczenie kategorii patriotyzmu jako ważnego składnika tworzonego przez niego wzorca władcy ${ }^{64}$, przytoczone przykłady można interpretować jako poważny zarzut sprzeniewierzenia się jednej z podstawowych powinności monarchy, czyli dbaniu o dobro państwa i własnych poddanych. Oskarżenie to nabiera szczególnej wagi w przypadku monarchów obcych, którym łatwiej można było zarzucić mniejszą dbałość o stan swego posiadania w drugim królestwie oraz pewną niefrasobliwość w rozporządzaniu podległymi im terenami.

Pojawienie się cudzoziemskiego króla, który przynajmniej na początku swoich rządów musiał pozyskać sobie przychylność nowych poddanych, skutkowało także nadawaniem części spośród nich przywilejów ekonomicznych, osłabiających skarb państwa. Długosz powiązał ten mocno przez siebie krytykowany proceder z osobą Władysława Jagiełły ${ }^{65}$.

Nie bez znaczenia dla oceny rządów obcego króla pozostawały problemy związane z komunikacją między poddanymi a nowym, cudzoziemskim monarchą. W przypadku Ludwika I kronikarz zaznaczał, jakoby jego polscy poddani mieli wysuwać pretensje, że muszą porozumiewać się ze swoim władcą za pośrednictwem tłumacza ${ }^{66}$. Bariery językowe, w połączeniu z częstą nieobecnością króla w jego drugim władztwie, utrudniały prawidłowe wywiązywanie się z obowiązków monarszych.

60 Tamże, s. 59.

61 Tamże, s. 172.

62 Podobnie negatywnie ocenił przekazanie przez Władysława księciu Witoldowi Podola, określonego jako część Królestwa Polskiego. Co więcej, decyzja ta miała zostać podjęta bez zgody panów polskich (tamże, lib. 10-11, s. 181-182). Z kolei układ Władysława z Zygmuntem z 1412 r. w opinii kronikarza podważał bezsporne prawa Królestwa Polskiego do Rusi i Podola oraz doprowadził do podziału będącej lennem polskim ziemi wołoskiej między Polskę a Węgry (tamże, s. 192).

63 Dla kontrastu, ponowne przyłączenie ziem ruskich do Królestwa Polskiego, dokonane przez Jadwigę, zostało przez Długosza określone mianem bohaterskiego czynu, którym zasłużyła sobie na wieczną pamięć Polaków (tamże, lib. 10, s. 182).

64 U. Borkowska: Treści ideowe..., s. 99.

65 Annales, lib. 10, s. 155.

66 Tamże, s. 20. 
Katalog wad panowania obcego monarchy zawarty w Rocznikach Jana Długosza nie jest oryginalny. Kronikarz czerpał obficie zarówno z tradycji filozoficznej, jak i z poglądów swoich poprzedników. I tak, w Sumie teologicznej św. Tomasza z Akwinu pojawiło się stwierdzenie, że królowie pochodzący $\mathrm{z}$ obcego narodu są mało doń przywiązani i w rezultacie zbytnio się o niego nie troszczą ${ }^{67}$. Obawy poddanych przed łamaniem przez cudzoziemskiego władcę obowiązujących w Polsce praw i zwyczajów oraz wątek otaczania się własnymi rodakami można odnaleźć w Kronice Janka z Czarnkowa ${ }^{68}$. Z kolei, opisując przewagę dziedzicznego i rodzimego monarchy nad elekcyjnym, pochodzącym z obcej dynastii, Długosz posiłkował się ustaleniami Idziego Rzymianina czy Jana z Dąbrówki, którego wykładów wysłuchiwał w latach $1428-1431^{69}$. W teorii politycznej wieków średnich, dobrze znanej piętnastowiecznym uczonym polskim związanym z Uniwersytetem Krakowskim, państwo przyrównywano do organizmu, natomiast monarchę - do jego głowy. Władca miał troszczyć się o właściwy stan całego organizmu-państwa, a więc strzec jego bezpieczeństwa, dobra poddanych, przyczyniać się do wzrostu potęgi swego władztwa oraz zapewniać sprawiedliwe rządy ${ }^{70}$. Zdarzało się, że z zadań stawianych monarsze nie wywiązywali się królowie pochodzący $\mathrm{z}$ dynastii piastowskiej, co spotykało się z naganą i surową oceną dziejopi$\mathrm{sa}^{71}$. Jednak przypadki przytoczonych zaniechań budziły szczególną czujność kronikarza w odniesieniu do cudzoziemskich władców. Ich brak znajomości miejscowych praw, obyczajów, tradycji lub niedostateczna wiedza o nich czy trudności z opanowaniem języka czyniły ich, w oczach dziejopisa, bardziej predestynowanymi do działań sprzecznych z interesem Królestwa Polskiego.

Stanowisko autora Roczników wobec obcokrajowców na tronie polskim mogło uwidaczniać się również w sposobie prowadzenia narracji oraz akcentowaniu pewnych zachowań, działań czy cech przypisywanym konkretnym władcom. Niekiedy były to zabiegi i uwagi bardzo subtelne, które na pierwszy

${ }^{67}$ Św. Tomasz z Akwinu: Suma teologiczna. Tłum. P. BeŁch. T. 13. Londyn 1986, s. 252.

${ }^{68}$ Wśród zagrożeń związanych z pojawieniem się na tronie polskim cudzoziemskiego władcy Janko z Czarnkowa wymieniał m.in. wprowadzanie obcych obyczajów czy faworyzowanie własnych rodaków (Kronika..., s. 648).

${ }^{69}$ M. Zwiercan: Model władcy w komentarzu Jana z Dąbrówki do Kroniki bt. Wincentego zwanego Kadtubkiem w wyktadzie uniwersyteckim w latach Jana Dlugosza. „Analecta Cracoviensia" 1984, T. 16, s. 237, 244.

${ }^{70} \mathrm{~W}$ ten sposób wypowiadał się m.in. anonimowy autor dzieła Figura sigilli regis, którego powstanie przyjmuje się na początek XV stulecia (R. JAwORSKI: Władca idealny $w$ świetle alegorycznego opisu pieczęci majestatowej Władysława Jagietty. W: Monarchia w średniowieczu. Władza nad ludźmi, władza nad terytorium. Studia ofiarowane Profesorowi Henrykowi Samsonowiczowi. Red. J. Pysiak, A. PieniąDZ-SkrzypCZAK, M.R. PAuk. Warszawa-Kraków 2002, s. 326; zob. również: K. OżóG: Król w refleksji uczonych polskich XV wieku. W: Król w Polsce XIV i XV wieku. Red. A. Marzec, M. Wilamowski. Kraków 2006, s. 10-13).

${ }^{71} \mathrm{~Np}$. w model idealnego władcy nie wpisywał się w Rocznikach Długosza Mieszko II, którego rządy doprowadziły do osłabienia państwa polskiego (Annales, lib. 1-2, s. 300, 311). 
rzut oka nie wiązały się z problemem obcości i oceny decyzji oraz działań monarszych. Niemniej jednak ich dokładna analiza pozwala na wysnucie pewnych wniosków.

Długosz w sposób pośredni, bardzo zawoalowany oceniał rządy czeskie w Polsce ${ }^{72}$. Zwraca bowiem uwagę czytelnika sympatia, z jaką kronikarz, opisując wydarzenia z roku 1300 - roku polskiego triumfu Przemyślidy — zaczął odnosić się do wygnanego Władysława Łokietka oraz zapoznawał odbiorcę z losami księcia tuż po gnieźnieńskiej koronacji Wacława II. I tak, chociaż nie omieszkał przypomnieć, że utrata przez Piasta kujawskiego władzy na ziemiach polskich stanowiła karę Bożą za uciski Kościoła i poddanych, to jednocześnie usprawiedliwiał księcia, pisząc, że pozostawał wtedy pod wpływem intrygantów. Sam Władysław zaś z wielką godnością i cierpliwością znosił swe wygnanie, co wzbudzało podziw wielu jego poddanych ${ }^{73}$. Niewykluczone, że opisy te miały ocieplić wizerunek rodzimego dynasty, przyszłego króla Polski ${ }^{74}$, wywodzącego się z dynastii panów przyrodzonych. Warto przy tym zwrócić uwagę na fakt ich konsekwentnego, kilkukrotnego powtórzenia przy okazji referowania wydarzeń rozgrywających się $\mathrm{w}$ ciągu jednego $\mathrm{roku}^{75}$ oraz na kontekst umieszczenia w tekście. Zmagania księcia polskiego z przeciwnościami losu pojawiają się po ukazaniu działań nowego króla Polski, a te — w odniesieniu do jego nowych nabytków — kończą się na koronacji i przekazaniu rządów na ziemiach polskich miejscowym możnym, starostom i namiestnikom. Wacław szybko powrócił do Pragi, by już nigdy nie pojawić się w swym nowym władztwie. Bierności Przemyślidy, zainteresowanego wewnętrznymi sprawami Czech czy możliwością pozyskania korony węgierskiej dla swego syna, zostały przeciwstawione aktywność i konsekwencja Łokietka.

Odnosząc się do okoliczności powołania na tron Ludwika, Długosz wskazywał na nieprzychylny stosunek doń szerokich warstw społeczeństwa Królestwa Polskiego, które patrzyło na sprawę następstwa tronu w Polsce przez pryzmat świetnego panowania Kazimierza Wielkiego: „Ex adventu autem Lu-

${ }^{72} \mathrm{Na}$ ocenę Wacława II jako króla Polski mogły oddziaływać odległość chronologiczna oraz długość jego panowania, obejmująca 5 lat rządów na ziemiach polskich.

${ }_{73}$ Annales, lib. 9, s. 14, 16, 22. Jednocześnie pielgrzymka Władysława Łokietka do Rzymu w 1300 r. i pokuta, którą tam czynił, miały doprowadzić do odpuszczenia mu grzechów (tamże, s. 15).

${ }^{74}$ A. Semkowicz twierdził, że przedstawione tu rysy charakteru księcia (upór, wytrwałość, cierpliwość) zostały najprawdopodobniej zaczerpnięte z tradycji ustnej (Krytyczny rozbiór Dziejów polskich..., s. 324).

75 Oczywiście fakt, że opis jakiegoś wydarzenia pojawiał się na kartach Roczników dwukrotnie, w niewielkich odstępach czasu, nie może być argumentem rozstrzygającym. Podobne sytuacje tłumaczy się tym, że kronikarz przeczytał o zdarzeniu w dwóch różnych źródłach i nie zorientował się, że chodzi o ten sam fakt (W. Drelicharz: Miejsce Excerpta ex fontibus incertis $w$ warsztacie historiograficznym Jana Dlugosza. W: Jan Dlugosz (1415-1480)..., s. 83). 
dovici Hungarie regis in Poloniam mediocris tenuisque et pene nulla dulcedo et voluptas tam militarium quam popularium animos invaserat, Kazimiri quippe nuper defuncti regis radicata caritas prohibebat, et Ludovico et cuicumque alteri moderato regi ei succedenti favorem impendi, cuius eciam imperium, respectu desiderat et adempti sibi regis permoti aspernabantur" ${ }^{76}$. Z przytoczonych słów wynika, że niechęć ogółu poddanych nie była skierowana przeciwko samemu Ludwikowi, ale zasadniczo przeciwko każdemu innemu obcemu kandydatowi. Szczególnie znamienne były słowa o przywiązaniu do króla Kazimierza.

Bardzo ciekawy pozostaje w tym kontekście opis rzekomej reakcji władcy Węgier na możliwość pozyskania korony polskiej. Mimo poczynionych wcześniej ustaleń między Kazimierzem Wielkim a Karolem Robertem Ludwik na wieść o śmierci swojego wuja miał długo wahać się, czy na czele wojska ruszyć do Polski, aby objąć wakujący tron. Monarcha Węgier obawiał się bowiem zarówno nowych rozruchów, jak i ewentualnych przeszkód ze strony córek czy wnuków Piasta ${ }^{77}$. Długosz, stylizując wypowiedź monarchy na przekaz biblijny, włożył w usta przedstawiciela dynastii andegaweńskiej ostrzeżenie przed potencjalnym niebezpieczeństwem, jakie mogło ściągnąć na oba królestwa przyjęcie korony polskiej. Ludwik twierdził, że „non convenire duos greges locis distantes ab uno pastore probe a morsibus luporum servari nec uni viro duas uxores legitime posse coniungi nec duos pontificatus in unum rite conferri, Romam vix despectum tugurium habentem duos simul reges ferre non potuisse"78. Siostrzeniec Kazimierza Wielkiego miał zostać „zniewolony” do objęcia władzy w Królestwie Polskim na skutek nalegań posłów polskich oraz swoich węgierskich doradców. Decyzję o przyjeździe do Polski podjął ostatecznie po przybyciu na Węgry poselstwa panów polskich, w skład którego wchodzili biskup krakowski Florian Mokrski i kanclerz Królestwa Polskiego Janusz Suchywilk. W konkluzji przedstawianych wydarzeń Długosz, uprzedzając fakty, dobitnie zaznaczył, że gdyby królowi pozwolono pozostać przy swoim stanowisku, państwo polskie nie zostałoby pozbawione części ziem i skarbów, do czego doszło w wyniku rządów Ludwika ${ }^{79}$. Przywołane w tym miejscu wahania monarsze nawiązują do adekwatnej sytuacji przedstawionej w części poświęconej dziejom bajecznym. Wówczas przed przyjęciem korony miał wzbraniać się założyciel przyszłej dynastii królów i książąt polskich — Piast. W tym przypadku wybór został jednak poprzedzony cudownymi wy-

${ }^{76}$ Annales, lib. 10, s. 16. O stosunku Jana Długosza do króla Kazimierza Wielkiego zob. J. SPerka: Obraz Kazimierza Wielkiego w Rocznikach Jana Dlugosza. W: Kazimierz Wielki: historia i tradycja. Red. M. JAGLARz. Niepołomice-Kraków 2010, s. 241—267 (Rocznik Niepołomicki, T. 2).

77 Annales, lib. 10, s. 14.

78 Tamże.

79 Tamże, s. $14-15$. 
darzeniami, jego panowanie zaś okazało się niezwykle pomyślne ${ }^{80}$. Różnica między dwoma przypadkami sprowadzała się także do rodowodu monarchy. Piast, mimo niskiego pochodzenia, wywodził się spośród Polaków ${ }^{81}$.

Bardzo mocno zaakcentowany i występujący jedynie w przekazie Długosza opór wewnętrzny Ludwika przed objęciem władzy w Polsce ${ }^{82}$ stanowił zapowiedź przyszłego, niezbyt udanego panowania. Ale ustęp ten można również odczytywać jako próbę usprawiedliwienia monarchy i częściowe zrzucenie odpowiedzialności na dostojników polskich. To właśnie oni, a nie król węgierski, doprowadzili do złamania prawa polskiego, sprzeniewierzając się zasadzie dziedziczenia tronu przez Piastów. W narracji Długosza można spotkać się też $\mathrm{z}$ innymi próbami tłumaczenia niedociągnięć rządów Ludwika. Podsumowując jego panowanie, kronikarz podkreślił, że zmarł po 12 latach rządów w Polsce, naznaczonych stanem wewnętrznego niepokoju oraz zamieszkami. Długosz wyjaśnił jednak, że król nie był w stanie ustabilizować sytuacji w kraju ze względu na wiek i choroby ${ }^{83}$.

Podstawowym źródłem wiedzy o panowaniu Ludwika I w Polsce była dla Długosza Kronika Janka z Czarnkowa, której zapisy w zdecydowanej większości powielił w Rocznikach. Zależność piętnastowiecznego kronikarza od starszego kolegi nie oznaczała jednak bezrefleksyjnego przenoszenia sądów i ocen tam zawartych. Przykładem jest chociażby wspomniany wcześniej opis rozterek, jakie miały targać Ludwikiem przed objęciem tronu w Polsce ${ }^{84}$. Różnica uwidoczniła się również w opisie koronacji tego władcy, która wedle Janka odbyła się z udziałem niewielkiego grona przedstawicieli szlachty, Długosz zaś podkreślał jej uroczystą oprawę oraz przybycie licznych prałatów i dostojników Królestwa Polskiego ${ }^{85}$, co bardziej odpowiadało randze tego wydarzenia

${ }^{80}$ Tamże, lib. 1, s. 161-162.

${ }^{81}$ Jan Długosz, opisując rzekome debaty panów dokonujących wyboru władcy po śmierci Popiela, wskazał na toczące się między nimi dyskusje. Szczególnie interesujące z punktu widzenia tematu niniejszego artykułu było przeciwstawienie zamiarom części możnych zainteresowanych zagarnięciem władzy twierdzenia innych, wedle których nie godziło się desygnować rodaka na księcia (tamże, s. 157). Zdaniem R. Sobotki, w tym ostatnim przekonaniu należy upatrywać oddziaływania poglądów wyrażanych w czasach kronikarza, uzasadniających osadzenie na tronie przedstawiciela dynastii andegaweńskiej (R. SовоткA: Powoływanie władcy..., s. 52, 98).

82 Więcej o okolicznościach towarzyszących przejmowaniu tronu polskiego przez Ludwika zob.: J. DĄBrowski: Ostatnie lata Ludwika Wielkiego 1370-1382. Kraków 2009, s. 148164; A. Marzec: Pod rzadami..., s. 35-39.

${ }_{83}$ Annales, lib. 10, s. 102-103. Więcej na ten temat zob. J. Nikodem: Jan Długosz o rzadach andegaweńskich..., s. 98-106.

${ }^{84}$ Janko z Czarnkowa podkreślał czynną postawę Andegawena wobec możliwości pozyskania tronu w Polsce po śmierci Kazimierza Wielkiego. Przypuszczać należy, że w tym fragmencie Roczników Długosz przedstawił własną interpretację wydarzeń, być może w jakimś stopniu inspirowaną istniejącą tradycją.

85 A. SemKowicz: Krytyczny rozbiór Dziejów polskich..., s. 32. 
oraz godności króla Polski. Wydaje się więc, że dziejopis nie podzielał wrogości Janka w stosunku do Ludwika mimo krytycznego stanowiska wobec jego rządów. Wpływ na różnice, jakie pojawiły się w dwóch dziełach, miały perspektywa czasowa oraz stopień zaangażowania emocjonalnego autorów wobec prezentowanych wydarzeń. Janko z Czarnkowa był nie tylko kronikarzem czasów andegaweńskich, ale również aktywnym uczestnikiem obozu przeciwników kandydatury Ludwika do tronu polskiego ${ }^{86}$. Długosz natomiast, tworzący kilkadziesiąt lat później, mógł mieć na uwadze inne racje. Pisząc o Ludwiku, pisał jednocześnie o ojcu Jadwigi, która na kartach Roczników została przedstawiona jako władczyni (niemal) idealna ${ }^{87}$, a o jej kanonizację zabiegał m.in. mentor kronikarza, kardynał Zbigniew Oleśnicki ${ }^{88}$. Długosz, pozostając wierny sferze faktograficznej przedstawionej przez Janka z Czarnkowa oraz własnemu przywiązaniu do dynastii piastowskiej, starał się mimo wszystko znaleźć usprawiedliwienie dla pewnych zachowań czy działań podejmowanych przez króla Ludwika.

Wśród szerzej opisanych w Rocznikach cudzoziemców na tronie polskim szczególny jest przypadek Władysława Jagiełły ${ }^{89}$. Nie tylko pochodził on z państwa ościennego, ale - w przeciwieństwie do Wacława II i Ludwika I wywodził się także z odmiennego kręgu cywilizacyjnego ${ }^{90}$, co było wykorzy-

${ }^{86}$ Więcej na temat stosunku Janka z Czarnkowa do Ludwika oraz rządów andegaweńskich w Polsce: J. Sieradzki: Polska wieku XIV. Studium z czasów Kazimierza Wielkiego. Warszawa 1959, s. 39-81; J. KŁoczowski: Ludwik Wielki jako król Polski w Kronice Janka z Czarnkowa. „Zeszyty Naukowe KUL” 1983, R. 26, nr 3, s. 31-49; D. Zydorek: Kronika Janka z Czarnkowa. Między prywatna a obywatelska powinnościa. W: Cognitioni gestorum. Studia $z$ dziejów średniowiecza dedykowane Profesorowi Jerzemu Strzelczykowi. Red. D.A. SiKorsKi, A.M. Wyrwa. Poznań 2006, s. 447-458; J. BieniaK: Jan (Janek) z Czarnkowa. Niedokończona kronika polska z XIV wieku. St. Źr. 2009, T. 47, s. 118, 126-127.

${ }^{87}$ Pewną rysą na Długoszowym wizerunku Jadwigi pozostaje przywołanie na kartach Roczników oskarżeń o niewierność, formułowanych pod adresem monarchini przez Habsburgów. Więcej na ten temat zob. J. Nikodem: Gniewosz - Jadwiga - Wilhelm. Krytyka przekazu „Annales” Jana Dlugosza. Prz. Hist. 2007, T. 98, nr 2, s. 184-186.

${ }_{88}$ M. KoczersKa: Zbigniew Oleśnicki i Kościól krakowski w czasach jego pontyfikatu. Warszawa 2004, s. 160.

${ }^{89}$ Sposób postrzegania tego władcy przez Jana Długosza doczekał się osobnych analiz, które wyszły spod pióra K. BIEdrowsKieJ-OchmańsKiej i J. OCHMAŃsKiego (Władysław Jagiełto w opiniach...), Jakuba SкомiдŁa (Jan Długosz o Władysławie II Jagielle. (Charakterystyka króla w świetle „Annales seu Cronicae incliti Regni Poloniae”). „Acta Universitatis Lodziensis. Folia Iuridica" 1994, T. 61, s. 15-31) czy ostatnio Adama TALARowskiego (Od poganina do króla arcychrześcijańskiego. Wizerunek Władysława Jagiełty w Rocznikach Jana Dlugosza. W: „Średniowiecze Polskie i Powszechne”. T. 9 (13). Red. J. SPerka, B. CzwouDRAK. Katowice 2017, s. 7-152).

${ }^{90}$ Odmienność kulturowa Litwinów została ukazana na przykładzie legendy o pochodzeniu tej nacji. Długosz wskazywał bowiem, że naród litewski, w przeciwieństwie do Polaków, wywodzi się ze starożytnego, a więc pogańskiego jeszcze, Rzymu. Dziejopis jako pierwszy miał sformułować twierdzenie o rzymskich korzeniach Litwinów, chociaż już w kronice Piotra 
stywane przeciwko niemu i Polsce przez niechętne dwory europejskie. W tym kontekście interesująca pozostaje wzmianka zamieszczona przez Długosza pod rokiem 1410. Kronikarz, omawiając wyrok wydany przez Wacława IV w sporze polsko-krzyżackim, przypisał królowi rzymskiemu stwierdzenie, że Królestwo Polskie nigdy więcej nie powinno wybierać sobie monarchy z Litwy lub ze Wschodu, ale spośród władców zachodnioeuropejskich ${ }^{91}$. Według Długosza słowa te, jako oburzająca i bezpodstawna próba ingerencji w wewnętrzne sprawy państwa polskiego, miały świadczyć o niesprawiedliwości wyroku i tym samym stanowić dodatkowy argument za jego odrzuceniem. Pytaniem otwartym pozostaje, czy mamy tu do czynienia z komentarzem odautorskim dziejopisa, w którym ujawnił swą niechęć do protoplasty dynastii jagiellońskiej, czy konstatacja ta stanowiła echo opinii wygłaszanych przez ówczesne elity polityczne bądź intelektualne Europy Środkowej ${ }^{92}$. Niezależnie jednak od źródła oraz kontekstu przytoczenia tej wypowiedzi Długosz w sposób bardzo dobitny dał wyraz swemu przekonaniu nie tylko o obcości, ale wręcz o wyobcowaniu Władysława na arenie międzynarodowej.

W odniesieniu do Jagiełly przed przyjęciem przezeń chrztu dziejopis nie unikał określenia „barbarus”93, co można przetłumaczyć jako „barbarzyński”, „nieokrzesany”, „pogański”94. Tożsame sformułowania pojawiają się w tekście kronikarza w opisach pogańskich praktyk Litwinów. Ocena króla częściowo zmieniała się po jego chrzcie. Symbolicznym wymiarem tej przemiany było zastąpienie na kartach dzieła kanonika krakowskiego imienia „Jagiełło” chrześcijańskim imieniem „Władysław" ${ }^{95}$. Od tej chwili kronikarz niejednokrotnie eksponował monarsze zaangażowanie w dzieło nawracania Litwinów — naj-

z Dusburga pojawiła się wzmianka o powiązaniu pruskiego miejsca kultu Romowe z pogańskim Rzymem (M. Kosman: Polacy o Litwinach (do połowy XVI wieku). W: Społeczeństwo Polski średniowiecznej. Red. S.K. KuczYŃsKi. T. 3. Warszawa 1985, s. 420). Więcej o tym problemie zob.: A. BoczKowska: Jan Dlugosz a legenda o rzymskim pochodzeniu Litwinów. „Rocznik Muzeum Narodowego w Warszawie” 1992, T. 36; E. Kulicka: Legenda o rzymskim pochodzeniu Litwinów i jej stosunek do mitu sarmackiego. Prz. Hist. 1980, T. 71, nr 2.

${ }_{91}$ Annales, lib. 10-11, s. 52. Owego stwierdzenia nie ma w wyroku Wacława IV (Rozbiór krytyczny..., s. 89).

${ }_{92}$ Autorzy Rozbioru krytycznego..., analizując ustęp o okolicznościach towarzyszących wydaniu wyroku przez Luksemburga, zwrócili uwagę na możliwość korzystania przez Długosza przy odtwarzaniu rokowań w Pradze z jakiegoś opisu czy protokołu sporządzonego przez naocznego świadka (Rozbiór krytyczny..., s. 88-89). Na temat opinii formułowanych pod wpływem propagandy luksembursko-krzyżackiej w państwach Europy Zachodniej po zwycięstwie grunwaldzkim Jagiełły zob. A.F. Grabski: Polska w opiniach Europy Zachodniej XIV$X V w$. Warszawa 1968, s. 237-300.

${ }_{93}$ Np. Annales, lib. 10, s. 149, 150, 155.

94 Stownik łaciny średniowiecznej w Polsce. T. 1: A-B. Red. M. Plezia. Wrocław-Kraków-Warszawa 1953-1958, s. 1043.

95 J. Sкомiaє: Jan Długosz o Władysławie II Jagielle..., s. 17. 
ważniejszą konsekwencję unii polsko-litewskiej ${ }^{96}$. Władysława II jako króla Polski charakteryzowała wielka gorliwość neofity, przejawiająca się w licznych fundacjach kościelnych czy klasztornych, skrupulatnie odnotowywanych na kartach Roczników, jak również w opisach praktyk religijnych monarchy ${ }^{97}$. Owe działania składały się na średniowieczny wizerunek władcy pobożnego. W przypadku panowania Władysława II, niedawnego poganina i ciemiężyciela chrześcijan, który ostatecznie zasiadł na tronie katolickiego państwa, miały one jednak dodatkowy wydźwięk. Ataki przeprowadzane przez Krzyżaków i Luksemburgów na osobę Jagiełły, dla których koronnym argumentem pozostawała rzekomo powierzchowna czy wręcz pozorna chrystianizacja Litwina oraz jego sympatie wobec schizmatyków i heretyków, uderzały w honor władcy Polski. Pomówienia formułowane przez przeciwników wymagały wykazania, że król-neofita podejmował stosowne działania. Przykładowo, pod rokiem 1412 Długosz przekazał informację o konsekrowaniu w Przemyślu kościoła katedralnego obrządku prawosławnego na kościół katolicki i usunięciu prochów pogrzebanych tam wcześniej Rusinów. Król miał w ten sposób oczyścić się ze stawianego mu przez Niemców zarzutu sprzyjania i protekcji schizmatyków ${ }^{98}$.

Podobnie można traktować mocno uwypuklone przez Długosza praktyki religijne Władysława przed bitwą grunwaldzką ${ }^{99}$. Monarcha wysłuchiwał kolejnych mszy ${ }^{100}$, nie zważając na grożące wojsku polskiemu niebezpieczeństwo

${ }^{96}$ Przekonanie to na kartach dzieła Długosza wyartykułował w 1429 r. Zbigniew Oleśnicki w mowie skierowanej do księcia Witolda: „Unum nos in his solatur doloribus, quod in suscepcione fratris Wladislai regis fidei sancte ampliacionem et salutem animarum intendebamus..." - Annales, lib. 11, s. 254.

${ }^{97}$ Np. tamże, s. 183; lib. 11-12, s. 124-125. Przejawy pobożności i respektowanie nakazów religijnych wpisywały się w średniowieczny model władcy idealnego (U. BorkowsKA: Treści ideowe..., s. 98-99). Na temat Długoszowego wizerunku idealnego władcy zob. też: M. Koczerska: Mentalnośćc..., s. 119-123. Ponadto: J. Skoczek: Ideat króla w średniowiecznej i renesansowej Polsce. "Sprawozdania Towarzystwa Naukowego we Lwowie” 1932, R. 12, z. 1, s. 17; S. GAWĘDA: Ocena niektórych problemów historii..., s. 200-201).

${ }_{98}$ Annales, lib. $10-11$, s. 211. W podobny sposób można potraktować informację podaną pod 1424 r. o zrzuceniu z mównicy i uwięzieniu kapłana husyckiego głoszącego kazanie na dworze monarszym w Wiślicy, co odbyło się za namową biskupa Zbigniewa (tamże, lib. 11, s. 199). Wiadomości tej nie przytaczają inne źródła, można ją znaleźć jedynie u Długosza (Rozbiór krytyczny..., s. 214).

${ }^{99}$ Więcej zob. A. Talarowski: Od poganina do króla arcychrześcijańskiego..., s. 139— 142.

100 Jedno z ważniejszych źródeł Długosza, na podstawie którego odtwarzał bitwę pod Grunwaldem, Cronica conflictus, powstałe tuż po zwycięstwie Jagiełły, również przekazało informację o uczestniczeniu przez króla w mszy przed rozpoczęciem zmagań militarnych. Jednak w narracji tego dzieła zadośćuczynienie przez monarchę praktykom religijnym nie kolidowało tak bardzo z jego obowiązkami jako dowódcy (Cronica conflictus Wladislai regis Poloniae cum cruciferis anno Christi 1410. Wyd. Z. Celichowski. Poznań 1911, s. 20-21). „Kronika konfliktu" nie zachowała się w oryginale, ale w skróconej kopii sporządzonej w XVI w. Zdaniem wydawcy Długosz korzystał z jej obszerniejszej wersji (Z. Celichowski: Wstęp. 
ze strony krzyżackiej ${ }^{101}$. Ostatecznie, to gorliwości religijnej, a nie umiejętnościom dowódczym król miał zawdzięczać zwycięstwo nad wrogiem ${ }^{102}$. Należy pamiętać, że kronikarz budował swój przekaz, odwołując się do pewnych schematów, gotowych wzorców narracyjnych, które następnie modyfikował zgodnie z potrzebami swego dzieła ${ }^{103}$. Zarówno przekazy poprzedzające opis, jak i te odnoszące się do samej bitwy pełne były symboli, które jednoznacznie wskazywały na opowiedzenie się Boga po stronie władcy Polski ${ }^{104}$. Kreowanie przez Długosza takiej roli Jagiełły w bitwie pod Grunwaldem, podnoszenie jego pobożności oraz udziału Opatrzności w pogromie Krzyżaków mogło mieć na celu uzasadnienie zwycięstwa odniesionego przez niedawnego poganina nad chrześcijańskimi braćmi zakonnymi. Przedstawiciele tego zakonu rycerskiego zostali tak naprawdę pokarani przez Siłę Wyższą, a monarcha Królestwa Polskiego i podległe mu rycerstwo stanowili jedynie narzędzie w rękach Boga. Długosz, eksponując w tym kontekście pobożność Władysława, mógł mieć na względzie osiągnięcie dwóch celów. Z jednej strony chodziło o przekonanie opinii publicznej, że dawny poganin Jagiełło — założyciel nowego rodu panującego w Polsce - stał się prawowiernym chrześcijańskim monarchą ${ }^{105}$, wpisując się tym samym w topos pobożnego władcy. $Z$ drugiej zaś, i to wydaje się o wiele ważniejsze dla niniejszych rozważań, kronikarz pragnął chronić wize-

W: Cronica conflictus..., s. 9-10). O stosunku tych dwóch źródeł zob.: A. Prochaska: Dtugosz a Cronica conflictus o bitwie grunwaldzkiej. Kw. Hist. 1910, T. 24, s. 407-421; M.A. JANICKI: O pewnych dogmatach $i$ kontrowersjach historiografii grunwaldzkiej: miejsce postoju Władystawa Jagietly przed bitwa pod Grunwaldem a miejsce obozowania po niej w świetle „Cronica conflictus” $i$ „Annales” Jana Dtugosza. W: „Średniowiecze Polskie i Powszechne”. T. 6 (10). Red. J. Sperka, B. CzWojdraK. Katowice 2014, s. $202-254$ (tam też aktualne zestawienie literatury przedmiotu).

101 „Et quamvis alter dux magnus Lithuanie, qui omnia facilius ferre poterat quam moram, Wladislaum regem quatenus Divinis et oracionibus neglectis consurgens properaret in bellum, cum hostium exercitus decernere paratus staret iam aliquanto tempore accinctus ad pugnam et periculum foret, si irruens arma prior inferret, variis precibus et instanciis primum per internuncios, deinde per se ipsum vociferacione ingenti vexasset, nullis tamen precibus, nulla obsecracione, nulla denique periculi denunciacione a Divinis et oracione poterat nisi complemento facto abduci. Poterat siquidem hostilis Pruthenicus exercitus quamvis robore inferior victoriam sibi vendicasse aut saltem ingentem cladem in Regni exercitum edidisse, si quam primum regis exercitum sine lege, sine ordine consistentem et locacione castrorum occupatum armatus ipse et paratus inermem et incautum invasisset" - Annales, lib. $10-11$, s. $87-88$.

102 Tamże, s. 88. W dalszej części opisu bitwy grunwaldzkiej kronikarz napisał o Władysławie: „Optimus plane rex, qui hostes suos non tam gladio quam mansuetudine et equitate vincebat, plus sacrificiis et oracione dimicans quam telis" — tamże, s. 104.

${ }_{103}$ M. BARTNICKI: Kwestia dowodzenia w bitwie grunwaldzkiej. W: 600-lecie bitwy pod Grunwaldem i jej tradycje. Red. G. Jakimińska, Z. NASALSKI, R. SzczygieŁ. Lublin 2012, s. $84-85$.

104 Tamże, s. 85.

105 J. Sкомiaє: Jan Dtugosz o Władystawie II Jagielle..., s. 29. 
runek Królestwa Polskiego, które dostało się pod panowanie obcego etnicznie i cywilizacyjnie króla.

Spośród trzech cudzoziemskich władców Polski jedynie w przypadku Władysława Jagiełły Długosz pokusił się o zamieszczenie obszernego podsumowania jego rządów. Obraz monarchy, jaki pojawił się w dziele, zasadniczo został uznany za pozytywny, a zalety przypisane Władysławowi miały częściowo niwelować wady znane z wcześniejszych ustępów Roczników ${ }^{106}$. Uważna lektura charakterystyki króla nie do końca jednak odpowiada temu twierdzeniu ${ }^{107}$. Ocena kronikarza nie była oczywiście warunkowana tylko i wyłącznie faktem obcości etnicznej, religijnej czy kulturowej Jagiełły. Niemniej jednak w podsumowaniu rządów Władysława dokonanym przez Długosza pojawiły się pewne wątki nawiązujące do cudzoziemskiego pochodzenia monarchy, które mogły wpływać na sądy dotyczące tego władcy. I tak, kronikarz napomknął o odmienności kulturowej króla, pisząc o praktykowaniu przezeń przesądów zaszczepionych mu przez matkę, wyznawczynię obrządku greckiego ${ }^{108}$. Jednak najpoważniejszy zarzut dotyczył wspomnianego już braku dbałości o Królestwo Polskie, którego sprawy podporządkowano interesom Litwy. Nadmierne przywiązanie Jagiełły do litewskiego dziedzictwa i litewskich krewnych powodowało, że nie wahał się on narażać Polski na różnego rodzaju niebezpieczeństwa oraz przeznaczać dochody królewskie na potrzeby swojej dawnej ojczyzny $^{109}$. Oskarżenia te nie tylko pozostają w sprzeczności z ideałem władcy, którego głównym zadaniem było dbanie o dobro powierzonego mu państwa ${ }^{110}$,

106 K. Biedrowska-Ochmańska, J. Ochmański: Władysław Jagiełto w opiniach..., s. 72.

107 Annales, lib. 11-12, s. 123-128. Długosz wskazywał na pewne cechy Jagiełły, które tradycyjnie uznawano za składające się na wizerunek dobrego króla (hojność dla Kościoła i poddanych, szczodrość i troska, zwłaszcza o ubogich, wdowy i sieroty, łagodność, życzliwość czy religijność), niemniej jednak i one finalnie mogły okazywać się szkodliwe z punktu widzenia interesów państwa. Np., wedle słów kronikarza, monarsza szczodrość i hojność przemieniały się w rozrzutność, wyrządzając wielką szkodę Królestwu. Łagodność zaś była mylona z wrodzoną ociężałością Litwina, ponadto sprawiała, że władca oszczędzał winowajców, którzy zasłużyli na karę.

108 Tamże, s. 125, 127.

109 Tamże, s. 125.

${ }^{110}$ K. Biedrowska-Ochmańska i J. Ochmański stwierdzili, że kronikarz nie rozumiał, że Jagiełło umacniający pozycję Litwy w jej walce z zakonem krzyżackim kosztem państwa polskiego bronił w ten sposób Polski. Dalej skonstatowano: „Toteż jego zarzuty pod adresem Władysława Jagiełły w istocie obracają się w pochwałę tego władcy — pochwałę nie tylko jego miłości do ziemi przodków, ale i w uznaniu dla jego polityki, która poprzez wzmocnienie odporności Litwy wobec Zakonu zmierzała do osiągnięcia przewagi nad odwiecznym wrogiem" K. Biedrowska-Ochmańska, J. Ochmański: Władysław Jagiełto w opiniach..., s. 67. Nie podważając przedstawionych interpretacji dwudziestowiecznych historyków, należy pamiętać, że opis nadmiernego przywiązania Jagiełły do księstwa litewskiego w opinii samego Długosza oraz środowiska, z którego się wywodził, nie mógł być uznany za przemawiający na korzyść władcy. 
ale też z propagowanym przez kanonika krakowskiego patriotyzmem ${ }^{111}$. Można je uznać za typowe negatywne konsekwencje przejęcia tronu przez przedstawiciela obcej dynastii.

Wyrażone w Rocznikach poglądy Jana Długosza na temat panowania cudzoziemskich władców w Królestwie Polskim były z reguły krytyczne. Kronikarz dostrzegał zdecydowaną przewagę wad takich rządów, przy niewielkich korzyściach z nich płynących. Można wskazać różne przyczyny formułowania takich opinii. Oprócz oddziaływania utartych w tradycji politycznej i przeddługoszowej historiografii poglądów na temat panujących z krajów ościennych istotne było przekonanie kronikarza o nadrzędności zasady dziedziczenia tronu w linii Piastów, którego to warunku z założenia nie mogli spełnić obcy kandydaci. Nie bez znaczenia pozostawały stereotypy, jakimi kanonik krakowski posługiwał się w odniesieniu nie tylko do obcych (np. pod względem etnicznym, religijnym, kulturowym itp.). Wydaje się jednak, że sprawą najistotniejszą było jego przywiązanie do dynastii Piastów, panów rodzimych i przyrodzonych Królestwa Polskiego, niedoskonałych, ale lepszych niż jacykolwiek cudzoziemcy.

\section{Bibliografia}

\section{Źródła drukowane}

Cronica conflictus Wladislai regis Poloniae cum cruciferis anno Christi 1410. Wyd. Z. CeliCHOWSKi. Poznań 1911.

Ioannis Dlugossi Annales seu Cronicae incliti Regni Poloniae. Lib. 1-2. Ed. I. DąBrowski. Varsaviae 1964; lib. 3-4, 5-6, 9. Ed. S. BudKowA et al. Varsaviae 1970-1978; lib. 10: 1370-1405. Ed. C. PieradzKa et al. Varsaviae 1985; lib. 10-11: 1406-1412. Ed. M. PleZIA et al. Varsaviae 1997; lib. 11: 1413-1430. Ed. G. Wyrozumski et al. Varsaviae 2000; lib. 11-12: 1431-1444. Ed. C. BACZKowski et al. Varsaviae 2001; lib. 12: 1445-1461. 1462-1480. Ed. G. Wyrozumski, C. Baczkowski et al. Cracoviae 2003-2005.

Jana Dlugosza Roczniki, czyli kroniki sławnego Królestwa Polskiego. Ks. 1-2. Red. J. DĄBRowski. Warszawa 1962; ks. 3-4, 5-6, 9. Red. Z. KozŁowska-Budkowa i in. War-

${ }^{111}$ Kronikarz potrafił zweryfikować swoje do tej pory niezbyt korzystne opinie o królu, jeżeli uznał, że ten zaczął działać na rzecz dobra monarchii i poddanych. I tak np. zwraca uwagę fakt zmiany nastawienia Długosza do Kazimierza Jagiellończyka po 1460 r., co wiązało się z odzyskaniem przez władcę Pomorza i przywróceniem tego terytorium Królestwu Polskiemu (U. Borkowska: Treści ideowe..., s. 117; R. Sовотка: Powoływanie władcy..., s. 17). 
szawa 1969-1975; ks. 10, 10—11. Red. S. GAWĘDA i in. Warszawa 1981—1985; ks. 11, 11 i 12, 12 (1445-1461), 12 (1462-1480). Red. K. BACZKowsKi i in. Warszawa 2004-2009. Kronika Janka z Czarnkowa. Wyd. A. Bielowski. W: Monumenta Poloniae Historica. T. 2. Lwów 1872.

Maciej z Miechowa: Opis Sarmacji azjatyckiej i europejskiej. Wstęp H. Barycz. Tłum.

T. BieŃKowski. Wrocław-Warszawa-Kraków—Gdańsk 1972.

Św. Tomasz z Akwinu: Suma teologiczna. Tłum. P. Bęch. T. 13. Londyn 1986.

\section{Opracowania}

BARTNICKi M.: Kwestia dowodzenia w bitwie grunwaldzkiej. W: 600-lecie bitwy pod Grunwaldem i jej tradycje. Red. G. Jakimińska, Z. NASAlski, R. Szczygiel. Lublin 2012.

Biedrowska-Ochmańska K., Ochmański J.: Władysław Jagiełlo w opiniach swoich wspótczesnych. Próba charakterystyki jego osobowości. Poznań 1987.

BieniaK J.: Jan (Janek) z Czarnkowa. Niedokończona kronika polska z XIV wieku. „Studia Źródłoznawcze" 2009, T. 47.

Biskup M.: Jan Dlugosz (1415-1480) jako historyk Polski i krajów Europy Środkowo-Wschodniej. „Zapiski Historyczne” 1981, T. 46, z. 4.

BobrzyŃski M., Smolka S.: Jan Długosz, jego życie i stanowisko w piśmiennictwie. Kraków 1893; reprint: Kraków 2015.

Boczkowska A.: Jan Dlugosz a legenda o rzymskim pochodzeniu Litwinów. „Rocznik Muzeum Narodowego w Warszawie" 1992, T. 36.

Bogucka M.: Kazimierz Jagiellończyk i jego czasy. Kraków 2009.

Borkowska U.: Historiograficzne poglady Jana Dlugosza. W: Dlugossiana. Studia historyczne w pięćsetlecie śmierci Jana Dlugosza. Red. S. GawęDa. Cz. 2. Warszawa-Kraków 1985.

Borkowska U.: Treści ideowe $w$ dziełach Jana Długosza. Kościót i świat poza kościołem. Lublin 1983.

Bukowski W.: Krag rodzinny Jana Dlugosza. W: Jan Dlugosz (1415-1480). Życie i dzieła. Red. L. Korczak, M.D. Kowalski, P. WęCowski. Kraków 2016.

DĄBrowska M.: Jana Dlugosza spojrzenie na Bizancjum. W: Sic erat in votis. Studia i szkice ofiarowane Profesorowi Zbigniewowi Anusikowi w sześćdziesiąta rocznicę urodzin. Europa i świat w czasach nowożytnych. Red. M. KaRкосна, P. RoвaK. Łódź 2017.

DĄBROWSKi J.: Ostatnie lata Ludwika Wielkiego 1370-1382. Kraków 2009.

Drelicharz W.: Miejsce Excerpta ex fontibus incertis $w$ warsztacie historiograficznym Jana Dtugosza. W: Jan Dlugosz (1415-1480). Życie i dzieła. Red. L. KorczaK, M.D. KowaLSKI, P. WĘCOWSKI. Kraków 2016.

GawęDA S.: Ocena niektórych problemów historii ojczystej w „Rocznikach” Jana Dlugosza. W: Dlugossiana. Studia historyczne w pięćsetlecie śmierci Jana Dlugosza. Red. S. GawęDA. Warszawa 1980.

Gawlas S.: Świadomość narodowa Jana Długosza. „Studia Źródłoznawcze” 1983, T. 27. GĄSIOROwski A.: Itinerarium króla Władysława Jagietty 1386-1434. Warszawa 1972. Grabski A.F.: Polska w opiniach Europy Zachodniej XIV-XV w. Warszawa 1968.

Grzesik R.: Polska Piastów i Węry Arpadów we wzajemnej opinii (do 1320 roku). Warszawa 2003. 
JANICKI M.A.: O pewnych dogmatach i kontrowersjach historiografii grunwaldzkiej: miejsce postoju Władystawa Jagietty przed bitwa pod Grunwaldem a miejsce obozowania po niej $w$ świetle „Cronica conflictus” $i$,Annales” Jana Dtugosza. W: „Średniowiecze Polskie i Powszechne”. T. 6 (10). Red. J. Sperka, B. Czwojdrak. Katowice 2014.

JAWORSKI R.: Władca idealny w świetle alegorycznego opisu pieczęci majestatowej Władysława Jagiełty. W: Monarchia w średniowieczu. Władza nad ludźmi, władza nad terytorium. Studia ofiarowane Profesorowi Henrykowi Samsonowiczowi. Red. J. Pysiak, A. PieniąDz-Skrzypczak, M.R. Pauk. Warszawa-Kraków 2002.

KŁoczowski J.: Ludwik Wielki jako król Polski w Kronice Janka z Czarnkowa. „Zeszyty Naukowe KUL" 1983, R. 26, nr 3.

Koczerska M.: Mentalność Jana Długosza w świetle jego twórczości. „Studia Źródłoznawcze” 1970, T. 15.

KocZerska M.: Zbigniew Oleśnicki i Kościót krakowski w czasach jego pontyfikatu. Warszawa 2004.

Korczak L.: Jan Dlugosz a Litwa - miejsca i ludzie. W: Jan Dlugosz (1415-1480). Życie $i$ dzieła. Red. L. Korczak, M.D. Kowalski, P. WęCowski. Kraków 2016.

Kosman M.: Polacy o Litwinach (do połowy XVI wieku). W: Społeczeństwo Polski średniowiecznej. Red. S.K. KuCZYŃsKi. T. 3. Warszawa 1985.

Kościelny R.: Jan Długosz a Czechy w świetle Annales. „Szczecińskie Studia Historyczne” 1987, nr 1.

Krzyżaniakowa J.: Niemcy w opinii Jana Dlugosza. W: Polacy i Niemcy. Dziesięć wieków sąsiedztwa. Red. A. CzubiŃsKi. Warszawa 1987.

KuCzyŃSki S.M.: Rozbiór krytyczny roku 1385 „Dziejów polskich” Jana Dlugosza. „Studia Źródłoznawcze" 1958, T. 3.

Kulicka E.: Legenda o rzymskim pochodzeniu Litwinów i jej stosunek do mitu sarmackiego. „Przegląd Historyczny” 1980, T. 71, nr 2.

KuPERA M.: Jan Dlugosz a Slovensko. „Zborník Filozofickej Fakulty Univerzity Komenského. Historica“ 1983, R. 34.

LeSHOck D.B.: Religious Geography: Designating Jews and Muslims as Foreigners in Medieval England. In: Meeting the Foreign in the Middle Ages. Ed. A. Classen. New YorkLondon 2002.

MačıUKas Ž.: Ksiązę Witold Wielki w kampanii letniej 1410 r. w ocenie Jana Dlugosza. „Annales Universitatis Paedagogicae Cracoviensis. Studia Historica” 2011, nr 1.

Marzec A.: Pod rządami nieobecnego monarchy. Królestwo Polskie 1370-1382. Kraków 2017.

Mikulka J.: Annales Jana Dtugosza a Czechy. „Odrodzenie i Reformacja w Polsce” 1963, T. 8.

Minea I.: Informaţile Româneşti ale cronicii lui Ian Dlugosz. Iaşi 1926; reedycja: Informaţiile româneşti în cronica lui Ian Díugosz. Bucureşti 1999.

Niкоdem J.: Gniewosz - Jadwiga - Wilhelm. Krytyka przekazu „Annales” Jana Dlugosza. „Przegląd Historyczny” 2007, T. 98, nr 2.

Nikodem J.: Jan Dtugosz o rządach andegaweńskich w Polsce. W: Jan Dlugosz - w kręgu badań historyków i literaturoznawców. Red. T. Giergiel. Sandomierz 2017.

Niкоdem J.: Spory o koronację wielkiego księcia Litwy Witolda w latach 1429-1430. Cz. 1: „Burza koronacyjna” w relacji Jana Dlugosza. „Lituano-Slavica Posnaniensia” 1994, T. 6.

Nikodem J.: Spory o koronację wielkiego księcia Litwy Witolda w latach 1429-1430. Cz. 2: Próba rekonstrukcji wydarzeń. „Lituano-Slavica Posnaniensia” 1995, T. 7.

Nikodem J.: Wróg Królestwa Polskiego. Zygmunt Luksemburski w opinii Jana Dlugosza. W: Cor hominis. Wielkie namiętności $w$ dziejach, źródłach i studiach nad przeszłością. Red. S. Rosik, P. Wiszewski. Wrocław 2007. 
Nikodem J.: Żmudź i Żmudzini w opinii Jana Dlugosza. W: Jan Dlugosz 600-lecie urodzin. Region - Polska - Europa w jego twórczości. Red. J. Maciejewski, P. Oliński, W. RoZYNKowski, S. Zonenberg. Toruń-Bydgoszcz 2016.

Obara-Pawlowska A.: Obraz Wołochów w piśmiennictwie Jana Dlugosza. „Balcanica Posnaniensia" 2017, T. 24.

OżóG K.: Król w refleksji uczonych polskich XV wieku. W: Król w Polsce XIV i XV wieku. Red. A. Marzec, M. Wilamowski. Kraków 2006.

Pentek Z.: Cesarstwo Eacińskie w oczach polskich dziejopisów od Jana Dlugosza do Macieja Stryjowskiego. „Balcanica Posnaniensia” 2013, T. 20.

Perzanowski Z.: Kanonik krakowski ks. Jan Dlugosz o królowej Jadwidze. „Analecta Cracoviensia" 1980, T. 12.

Pieradzka K.: Wiadomości o Burgundii u Jana Dtugosza. W: „Zeszyty Naukowe Uniwersytetu Jagiellońskiego". Prace historyczne, nr 56. Kraków 1977.

PleszCZyŃsKi A.: Niemcy wobec pierwszej dynastii piastowskiej (963-1034). Narodziny stereotypu. Postrzeganie i cywilizacyjna klasyfikacja władców Polski i ich kraju. Lublin 2008.

Prochaska A.: Dtugosz a Cronica conflictus o bitwie grunwaldzkiej. „Kwartalnik Historyczny" 1910, T. 24.

Romańczuk J.: Olgierd i Kiejstut w opinii Dlugosza. „Kuźnia Młodych Historyków” 2004, T. 1.

Rozbiór krytyczny Annalium Poloniae Jana Dlugosza. T. 1: Z lat 1285-1444. Oprac. S. GawĘDA $\mathrm{i}$ in. Wrocław 1961.

Russocki S.: Struktury i świadomość. Procesy integracji rycerstwa Europy Środkowej schyłku XIII w. i ich odbicie w historiografii epoki. W: Społeczeństwo Polski średniowiecznej. Red. S.K. KuCZYŃsKi. T. 1. Warszawa 1981.

Russocki S.: Średniowieczne narody polityczne środkowej Europy. „Czasopismo Prawno-Historyczne" 1985, T. 37, z. 2.

RzePiela M.: Rola frazeologii w narracji Kroniki Jana Dlugosza. W: Jan Dhugosz (14151480). Życie i dzieła. Red. L. KorczaK, M.D. Kowalski, P. WęCowsKi. Kraków 2016.

Semkowicz A.: Krytyczny rozbiór Dziejów polskich Jana Dlugosza (do roku 1384). Kraków 1882.

Sieradzki J.: Polska wieku XIV. Studium z czasów Kazimierza Wielkiego. Warszawa 1959.

Skoczer J.: Ideat króla w średniowiecznej i renesansowej Polsce. „Sprawozdania Towarzystwa Naukowego we Lwowie" 1932, R. 12, z. 1.

Sкомiaє J.: Jan Dlugosz o Litwie i Litwinach. W: Wielokulturowość polskiego pogranicza. Ludzie, idee, prawo. Red. A. LityŃski, P. FiedorCZYK. Białystok 2003.

Sкоміає J.: Jan Dlugosz o Władysławie II Jagielle. (Charakterystyka króla w świetle „Annales seu Cronicae incliti Regni Poloniae”). „Acta Universitatis Lodziensis. Folia Iuridica” 1994, T. 61.

Sкомiat J.: Polski portret litewskiego władcy. Witold Kiejstutowicz w świetle Annales Jana Dlugosza. W: „Rodzinna Europa”. Europejska myśl polityczno-prawna u progu XXI wie$k u$. Red. P. Fiktus, H. Malewsi, M. Marszal. Wrocław 2015.

Stownik łaciny średniowiecznej w Polsce. T. 1: A-B. Red. M. Plezia. Wrocław-KrakówWarszawa 1953-1958.

Sовотка R.: Powoływanie władcy w Rocznikach Jana Dlugosza. Warszawa 2005.

Solicki S.: Wiadomości geograficzne o Czechach w „Annales Poloniae” Jana Dlugosza. „Śląski Kwartalnik Historyczny Sobótka" 1981, T. 36, z. 1.

Solicki S.: Źródła Jana Długosza do problematyki czeskiej. Wrocław 1973.

SPerka J.: Obraz Kazimierza Wielkiego w Rocznikach Jana Dlugosza. W: Kazimierz Wielki: historia i tradycja. Red. M. JAGLARz. Niepołomice-Kraków 2010 (Rocznik Niepołomicki, T. 2). 
Sperka J.: Rządy namiestnicze Władysława Opolczyka w Królestwie Polskim. W: Mieszczanie, wasale, zakonnicy. Red. B. ŚLIwı́́sKi. Malbork 2004.

SwieżAwski A.: Butgaria w Annales Poloniae Jana Dtugosza. „Balcanica Posnaniensia” 1985, T. 2.

Swoboda W.: Bizancjum w przekazach Annales Jana Dtugosza. „Balcanica Posnaniensia” 1989, T. 4.

SzAfer K.: Wizerunek dobrej i złej władczyni w Rocznikach Jana Dlugosza. W: Kobieta w kulturze średniowiecznej Europy. Prace ofiarowane Profesor Alicji Kartowskiej-Kamzowej. Red. A. GĄsiorowski. Poznań 1999.

Szymańska M.: Opinia o Rusi do czasu właczenia do Polski Rusi Halickiej (1387), w „Kronice” Jana Długosza. „Kuźnia Młodych Historyków” 2004, T. 1.

TAlarowski A.: Od poganina do króla arcychrześcijańskiego. Wizerunek Władysława Jagietly w Rocznikach Jana Dtugosza. W: „Średniowiecze Polskie i Powszechne”. T. 9 (13). Red. J. Sperka, B. Czwojdrak. Katowice 2017.

TęGOWsKi J.: Bezkrólewie po śmierci Ludwika Wegierskiego a geneza unii Polski z Litwą. W: Studia historyczne z XIII-XV wieku. Red. J. ŚLIwIŃsKI. Olsztyn 1995.

WróBel D.: Bezkrólewie, matoletniość i nieobecność władcy w Rocznikach Jana Dlugosza. W: Jan Dlugosz (1415-1480). Życie i dzieła. Red. L. KorCZAK, M.D. KowalsKi, P. WęCowSKI. Kraków 2016.

Zahajkiewicz M.T.: Chrzest Litwy. Wprowadzenie. Problem chrztu Litwy w historiografii. W: Chrzest Litwy. Geneza, przebieg, konsekwencje. Red. M.T. Zahajkiewicz. Lublin 1990.

Zwiercan M.: Model władcy w komentarzu Jana z Dąbrówki do Kroniki bt. Wincentego zwanego Kadtubkiem $w$ wyktadzie uniwersyteckim w latach Jana Dlugosza. „Analecta Cracoviensia" 1984, T. 16.

Zydorek D.: Kronika Janka z Czarnkowa. Między prywatna a obywatelska powinnościa. W: Cognitioni gestorum. Studia z dziejów średniowiecza dedykowane Profesorowi Jerzemu Strzelczykowi. Red. D.A. SiKorsKi, A.M. Wyrwa. Poznań 2006.

\section{Anna Obara-Pawlowska}

\section{The Attitude of Jan Długosz Towards Foreign Rulers on the Polish Throne}

Summary

The aim of the following article is to present the attitudes of Jan Długosz towards the issue of crowning the representatives of foreign dynasties as kings of Poland. Thus, the article focuses on Długosz's opinions regarding the following rulers of Poland: Wenceslaus II of Bohemia, Louis I of Hungary and Władysław II Jagiełło, who all came to Poland from the neighboring countries and who represented dynasties other than the Piast dynasty. To this end, the article presents Długosz's opinions regarding the ascensions of foreign monarchs to the throne in the Kingdom of Poland, as well as discusses both the benefits and the disadvantages of having a foreign ruler on the throne, included in his Annales. In the last section of the article, referring to the descriptions of the monarchs' reigns found in Długosz's opus magnum, attempts to ascertain the influence of their foreign (ethnically, religiously or culturally) ancestry on the subject matter of Długosz's comments. 
Key words: Jan Długosz, foreign dynasty, Kingdom of Poland, the Middle Ages, Wenceslaus II of Bohemia, Louis I of Hungary, Władysław II Jagiełło

Anna Obara-Pawtowska

Stellungnahme von Jan Długosz zu ausländischen Herrschern
auf dem polnischen Thron

Zusammenfassung

Der Zweck des vorliegenden Artikels ist, die Ansichten von Jan Długosz über die Vertreter ausländischer Dynastien auf dem polnischen Thron zu präsentieren. Im Mittelpunkt des Interesses stehen die vom Chronisten zur Sprache gebrachten Meinungen über die Herrschenden in Polen: Wenzel II. Přemyslid, Ludwig I. von Anjou und Władysław II. Jagiełło als Monarchen, die aus den Nachbarländern stammten und die Herrscherhäuser nichtpiastischen Stammes repräsentierten. Im Artikel werden sowohl die Ansichten von Długosz über die Machtergreifung durch die fremden Dynasten im Königreich Polen näher gebracht, als auch werden die im Werk Annalen zitierten Vor- und Nachteile diskutiert, die aus der Herrschaft eines ausländischen Herrschers resultieren. Im letzten Teil der Ausführungen, in denen man sich auf die im Werk des Chronisten enthaltene Beschreibung der polnischen Regierung von den drei Monarchen bezieht, wird ein Versuch unternommen, die Auswirkung fremder (z.B. ethnischer, religiöser oder kultureller) Herkunft dieser Herrscher auf die Urteile zu erfassen, die über sie von Długosz abgegeben wurden.

Schlüsselwörter: Jan Długosz, fremde Dynastie, Königreich Polen, Mittelalter, Wenzel II. Přemyslid, Ludwig I. von Anjou, Władysław II. Jagiełło 